\title{
FEED-BORNE BACILLUS CEREUS: AN EIMERGING THREAT TO FOOD CHAIN RELATED HAZARD, SAFETY AND PATHOGENIC POTENTIALITY
}

\author{
Md Atiqul Haque', Ahrar Khan² and Cheng $\mathrm{He}^{1 *}$
}

'Key Lab of Animal Epidemiology and Zoonoses of Ministry of Agriculture and Rural Affairs; College of Veterinary Medicine, China Agricultural University, Beijing, 100193, China

${ }^{2}$ Shandong Vocational Animal Science and Veterinary College, Weifang, 261061, China

*Corresponding author: hecheng@cau.edu.cn

\section{INTRODUCTION}

Bacillus cereus is a Gram-positive, rod-shaped, motile (flagellated), aerobic or facultative anaerobic, spore and biofilm forming bacterium, commonly found in nature. It belongs to a group of genetically similar forms assigned to the genus Bacillus, consisting of several closely related species. This opportunistic pathogen is often isolated from food and gastrointestinal disorders, as well as from nongastrointestinal infections. Furthermore, it leads to vomiting and diarrheal syndromes in both animals and humans, which are linked to quickly fatal systemic and local infections, notably in neonates and immunosuppressed hospitalized patients. The ability of these pathogens to sporulate, and production of lipases and thermostable proteases allows them to withstand the common cleaning procedures in the food industry, resulting in finished product defects and food poisoning outbreaks.

B. cereus has also been used as a probiotic in human medicine and livestock production, but due to low standards of safety evaluation, toxins production, transfer of toxins and antibiotic resistance gene (ARG) in humans via the food chain, it is potentially posing a new threat to food safety. Consequently, feed-borne $B$. cereus contamination worsens extreme diarrhea and malnutrition in poultry by causing gizzard erosion and ulceration (GEU) syndrome, as well as hemorrhagic inflammation in lungs and immunosuppression, when coinfected with other pathogens. Considering the pathogenic potential of the entire $B$. cereus group, it is critical to gain insight into their genomes through wholegenome sequencing and gene analysis. This chapter includes an overview of the historical data on possible risk factors and pathogenesis of feed-borne $B$. cereus from animal feed to the human food chain, along with their implications for the food industry, focusing on food safety risks, classical and molecular analysis, advanced diagnostic methods, and their diversity, sensitivity, and ability to discover toxic and nontoxic bacteria.

\section{Background and Taxonomy}

The word "bacillus" means a "small rod," while the Latin word "cereus" refers to "wax-like", mostly used interchangeably with any "aerobic endospore-forming bacterium" (AEFB), which was first isolated from air in a cowshed in 1887 by Frankland and Frankland and discovered in 1906 by Plazikowski in connection with food poisoning in Europe (Fritze and Pukall 2011; Haque et al. 2021). B. cereus was first linked to food poisoning in the 1950s, when outbreaks of vanilla sauce poisoning were reported in Norway (Eglezos and Dykes 2014). B. cereus spores can last for years, even surviving during cooking due to their resistance to extreme temperatures, their growth is optimal in the presence of oxygen, but it can also thrive in anaerobic conditions, or at very low or high temperatures (Lutpiatina 2020).

There are currently 376 species in the Bacillus genus, with the $B$. subtilis and $B$. cereus group being two of the most common, however, several gene structures and regulatory mechanisms vary between these two groups of bacteria (Yin et al. 2020). B. amyloliquefaciens, B. atrophaeus, B. licheniformis, B. mojavensis, $B$. paralicheniformis, $B$. pumilus, $B$. subtilis, $B$. tequilensis, $B$. vallismortis, and $B$. velezensis are all members of $B$. subtilis group, while $B$. cereus group includes $B$. anthracis, $B$. cereus sensu stricto (s.s.) (usually referred to as B. cereus), B. mycoides, B. pseudomycoides, B. thuringiensis, B. weihenstephanensis, $B$. cytotoxicus, and B. toyonensis (Lindbäck and Granum 2019; Yin et al. 2020; Haque et al. 2021). Currently, $B$. cereus group has been divided into: i) genomospecies such as, B. pseudomycoides, B. paramycoides, B. mosaicus, $B$. cereus s.s., B. toyonensis, B. mycoides, B. cytotoxicus, and $B$. luti; ii) putative genomospecies such as, $B$. bingmayongensis, B. gaemokensis, B. manliponensis, and $B$. clarus; iii) subspecies such as, B. mosaicus subsp. anthracis, B. mosaicus subsp. Cereus; iv) Biovars such as Biovar Anthracis, Biovar Emeticus and Biovar Thuringiensis (Carroll et al. 2020). Even though the $B$. cereus group is phylogenetically heterogeneous in general, single strains with highly similar $16 \mathrm{~S}$ and $23 \mathrm{~S}$ rRNA sequences, especially $B$. cereus or $B$. cereus s.s., $B$. thuringiensis, B. anthracis and B. toyonensis isolates, can be considered as single species due to transfer of virulence factors through plasmids; these are also subsumed under 'B. cereus sensu lato' (Ehling-Schulz and Messelhäusser 2012; Griffiths and Schraft 2017; Lindbäck and Granum 2019). B. thuringiensis produces $\delta$-enterotoxin (BT toxin), which appears as a crystalline parasporal inclusion body and is insecticidal, making it a biopesticide; $B$. anthracis is the causative agent of anthrax in human and animals; spores of this organism may be used in bioterrorism; $B$. toyonensis is the current species designation for $B$. cereus 
var. toyoi strain that has been used as a fattening farm animals feed additive under the brand name of Toyocerin (Pontieri 2016; Griffiths and Schraft 2017).

$B$. cereus s.s. has been increasingly recognized as an evolving foodborne pathogen, with enterotoxins capable of causing emetic or diarrheic gastroenteritis in recent years (Pontieri 2016). It may also lead to local skin and wound infections, ocular infections (panophthalmitis, endophthalmitis, and keratitis), fulminant liver failure, and pervasive disease in cancer patients, such as endocarditis, osteomyelitis, pneumonia, brain abscess, meningitis myelodysplasia and extreme bacteremia.

\section{Characteristics of the organism, growth and reservoirs}

B. cereus are ubiquitous bacteria that can be found in decaying organic matter, air, dust, fresh and marine water, rhizosphere, animal and plant materials, vegetables, fomites, invertebrates' guts, beddings, feed and feedstuffs, pasture, with their adhesive spores can tolerate adverse conditions, like average cooking temperature, heat, dehydration, radiation and other physical stresses (Kumari and Sarkar 2016; Ramarao et al. 2020). Bacillus cells range in size from $0.5 \times 1.2$ to $2.5 \times 10 \mu \mathrm{m}$ and contain oval or cylinder-shaped spores that do not disclose the sporangia clustered in individual or short chains and located centrally, subterminally, or terminally (Fig. 1). The hydrophobic structure of the spores and presence of protrusions (1-30 in number of 0.45-3.8 $\mu \mathrm{m} \times 13.6 \mathrm{~nm}$ ) on the exterior result in strong adhesion to food processing surfaces, such as stainless steel. Bacillus species bacteria quickly sporulate in most media after 1 to 3 days (Kumari and Sarkar 2016; Grutsch et al. 2018; Lindbäck and Grnum 2019). They grow best at temperatures between $28-40^{\circ} \mathrm{C}$, while they can multiply at a temperature between $4-50^{\circ} \mathrm{C}$. Thermophilic varieties, on the other hand, grow best at $65^{\circ} \mathrm{C}$. A water activity $\left(\mathrm{a}_{\mathrm{w}}\right) \geq 0.91$, a $\mathrm{pH}$ of $4.0-9.3$ (optimal 7.0) and a $\mathrm{NaCl}$ concentration $<10 \%$ are also required for their development. Under ideal conditions, growing time is between 12 and 27 minutes (Eglezos and Dykes 2014). Bacillus spp. colony morphology varies by species, but they all grow on common agar media, like nutrient agar (NA) or plate count agar (PCA), producing large colonies (3-8 $\mathrm{mm}$ in diameter) with a flat, greyish and 'groundglass' appearance, sometimes with irregular borders. They metabolize organic substrates, like amino acids, organic acids, and sugars through aerobic/anaerobic respiration, or fermentation, depending on species and environment (Kumari and Sarkar 2016; Grutsch et al. 2018; Ramarao et al. 2020).

\section{Mode of transmission and contamination}

B. cereus is a common soil saprophyte that can be found in a variety of environmental habitats, as well as man-made settings, such as food manufacturing plants, food handling and processing facilities, transportation vehicles and hospital environments, where they may constitute reservoirs for the disease. Such habitats can provide a favorable environment for Bacillus spp. production, or may still harbor spores, which can quickly be transmitted to different raw foods, such as grain and cereals products, dried herbs, spices, eggs, milk and dairy products, fruit, vegetables, meat products, sauces, puddings, sprouts, rice and other carbohydrate-rich foods, as well as commercial RTE meals and products, which may become contaminated, resulting in transient colonization of the animal and human intestine (Fritze and Pukall 2011; Eglezos and Dykes 2014). B. cereus spores can become contaminant in the dairy sector when they come in contact with cows' udders during pasture or by feed or bedding material, then move into the raw milk. The spores may also withstand pasteurization, dehydration, $\gamma$ radiation, and other physical stresses (Grutsch et al. 2018; Lindbäck and Grnum 2019). The ability of $B$. cereus to bind firmly to surfaces and form biofilms, which shield their cells and spores against the antimicrobial action of sanitizers, accounting for their survival in food processing environments (Grutsch et al. 2018). Intake of food or air or a wound in the body contaminates spores or vegetative cells (Ramarao et al. 2020).

\section{Virulence factors and Pathogenicity}

B. cereus is most commonly associated with food poisoning and other serious systemic and local infections, owing to the synergistic effects of a range of virulence factors that foster intestinal cell disruption and/or immune system tolerance in the host. Table 1 summarizes the substances formed by $B$. cereus during bacterial growth, primarily enterotoxins, hemolysins, phospholipases and emetic toxin.

\section{Incidence of illness and outbreak data}

The exact incidence of the $B$. cereus food-borne poisoning is mysterious for many reasons: a) it is widely underestimated because the symptoms of the disease are intermittent $(<24 \mathrm{~h})$, slight, and self-limiting, so people do not seek treatment; b) most of the community is partially covered by resistance gained through chronic exposure; c) large numbers are needed to induce infection; d) symptoms are usually misdiagnosed with clostridial or Staphylococcus aureus intoxications (Griffiths and Schraft 2017). B. cereus appears to be responsible for $1.4-12 \%$ global food-borne illness outbreaks (Grutsch et al. 2018). Tables 2 and 3 summarize the outbreak and occurrence data for $B$. cereus poisoning over the last two decades.

\section{Pathogenesis of the diseases}

$B$. cereus and other members of the $B$. cereus group induce two forms of food poisoning: emetic syndrome and diarrheal illness. The emetic (vomiting) syndrome, which is similar to Staphylococcus aureus poisoning, is exacerbated by a ready toxin found in cooked rice and other cereal-based foods that resist high temperatures, trypsin, pepsin, and $\mathrm{pH}$; whereas the diarrheal illness, which is similar to Clostridium perfringens poisoning, 
Table 1: Virulence factors of B. cereus

\begin{tabular}{ll}
\hline Virulence factors & Properties \\
\hline Emetic toxins & \\
Cereulide $(\mathrm{Ces})$ & $\begin{array}{l}\text { Thermo-stable, Cyclopeptide }(1.2 \mathrm{kDa}) \text {, hepatic and immune } \\
\text { dysfunction, toxic in various mammalian cell lines, cerebral effects, } \\
\text { bioaccumulation in vital organs and necrotic cell death }\end{array}$
\end{tabular}

Enterotoxins

Hemolysin BL ( $\mathrm{Hbl})$

Nonhemolytic enterotoxin

(Nhe)

Cytotoxin K (CytK)

Enterotoxin FM (entFM)/

CwpFM

Enterotoxin T (entT)

Hydrolytic enzymes

Hemolysin I (HlyI)/ Cereolysin $\mathrm{O}$

Hemolysin II (HlyII)

Hemolysin III (HlyIII)

Phospholipase C/ Cerolysin A

Phosphatidylinositol specific

phospholipases C (PI-PLC)

Phosphatidylcholine specific

phospholipases C (PC-PLC)

Sphingomyelinase

(SMase)/Cerolysin B

Cerolysin $\mathrm{AB}$

Camelysin

Immune inhibitor $A_{1}$ (InhAl)

Bacillolysin

Neutral metallopeptidases/

Neutral protease

IlsA

Collagenase

Antibiotic resistance

$\beta$-lactamase I

$\beta$-lactamase II

$\beta$-lactamase III

Thermo-labile, protein, 3 components (35, 36, \& $45 \mathrm{kDa}$ ), pore formation, hemolysis, cytotoxicity, dermonecrotic and capillary permeability

Thermo-labile, protein, 3 components $(39,45, \& 105 \mathrm{kDa})$, pore

formation, intestinal fluid secretion, osmotic and Vero cell lysis, cell death

Thermo-labile, single-cell protein ( $34 \mathrm{kDa})$, pore formation, hemolysis, cytotoxicity and necrosis

Single-cell protein (45 kDa), cell wall peptidase, hemolysis, capillary permeability and cytotoxicity

Single-cell protein $(40 / 41 \mathrm{kDa})$, diarrheal toxigenicity, capillary

permeability and cytotoxicity

pore formation

Thermo-labile, cholesterol-independent, cytotoxicity, pore formation, hlyII

apoptosis in macrophages (caspase-3,8 pathways)

Hemolysis, transmembrane pore formation

Degradation of neutrophils

Destroying of protein harborage on plasma membranes

A small, monomeric enzyme (28.5 kDa), general hydrolytic action,

hemolysis, involved in substrate binding and necessary for enzymatic $p c p l C / p l c B$

activity and protein formation

Hemolytic protein that binds to sphingomyelin on erythrocytes,

hemolysis, decrease in phagocytosis, dodging macrophage in initial

phases of infection

2 components (PC-PLC+Smase) cytolysin, that function together to

lyse human erythrocytes

A cell-bound metalloprotease, capability to cleave hemoglobin,

albumin and casein in non-gastrointestinal infections
A zinc metalloprotease, efficient escape from macrophages

A metalloprotease

Proteolytic activity

Iron-regulated, leucine-rich surface protein, iron deprivation in the host

Degraded soluble and insoluble collagens, Azocoll, gelatin and bradykinin

$\operatorname{inh} A$
$n p r A$
$N p r / n p r B$

$i l s A$

cola

Class A $\beta$-lactamases and is an extracellular penicillinase with a serine blaı in the active site

Class B $\beta$-lactamase, is activated by binding Zn (II) and Co(II) ions blaz

Class A membrane-bound lipoprotein also having a secreted form $\quad B l m$

Encoded gene Reference

ces

Carlin and

Nguyen-The

(2013); Lindbäck

and Granum

(2015); Visiello

hblA, hblB, et al. (2016);

hblC, hblD Ehling-Schulz et

al. (2019);

nheA, nheB, Haque et al.

nheC (2021)

cytK1, cytK2

entFM/

cwpFM

bceT

Clo

hly-III

plC

piplC/plcA

sph

$\operatorname{cer} A B$

is provoked by a complex enterotoxin throughout vegetative growth of $B$. cereus in the small intestine, mainly linked to proteinaceous foods (Eglezos and Dykes 2014; Haque et al. 2021). Table 4 shows the key characteristics of $B$. cereus poisoning found in food and feed. According to our earlier studies, feed-borne $B$. cereus caused GEU, as well as hemorrhagic inflammation in lungs of chicken. Co-infection with other pathogens, such as avian influenza virus $\left(\mathrm{H}_{9} \mathrm{~N}_{2}\right)$ and Chlamydia psittaci worsened acute diarrhea and led to the development of
GEU and immunosuppression in birds. Importantly, $\mathrm{Hbl}$ and Cytk, enterotoxins of B. cereus, disrupt the koilin layer of the gizzard, causing long-term ulceration, necrosis, mucosal damage and diarrhea by damaging the digestive tract (Zhang et al. 2019; Zuo et al. 2020).

In a recent study, it was found that stomach ulceration caused by feed-borne $B$. cereus in conjunction with severe diarrhea, and co-infection with Aspergillus fumigatus alleviated gastric lesions and immunosuppression in weaned piglets ( $\mathrm{Li}$ et al. 2020). 

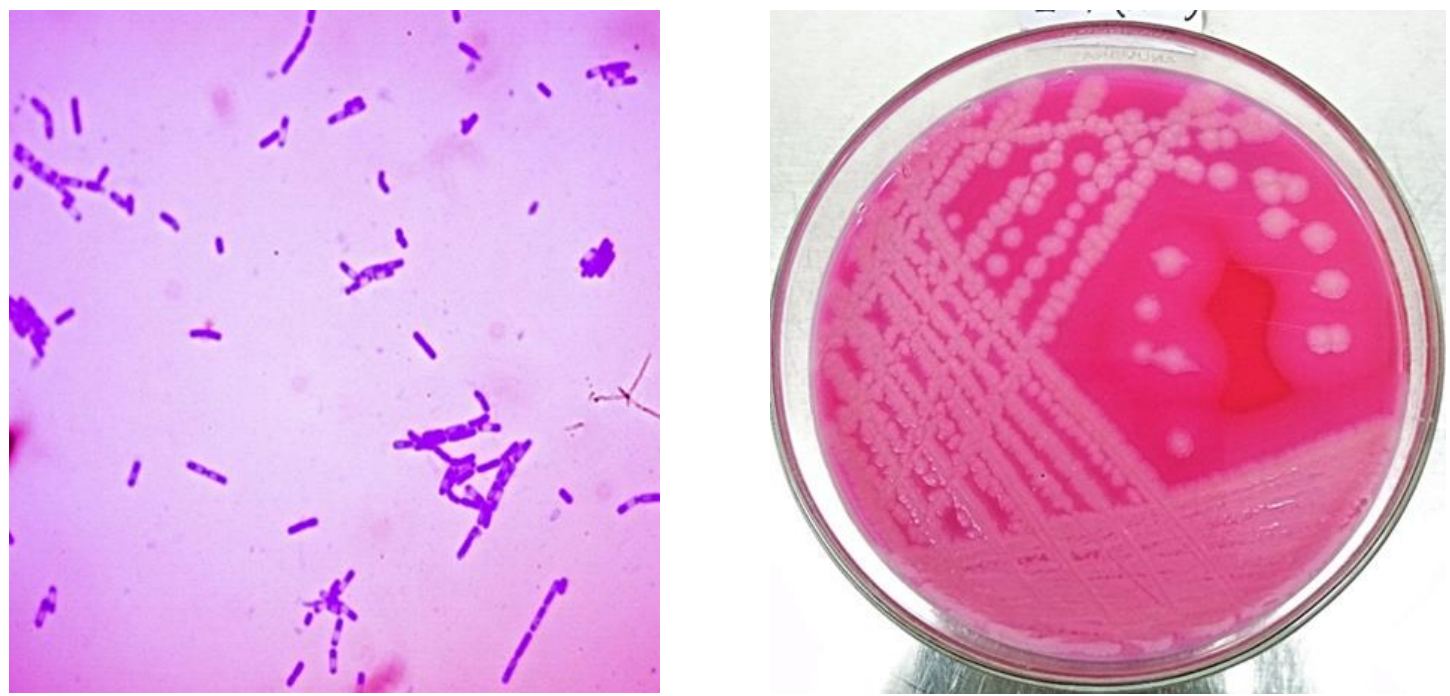

Fig. 1: Bacillus cereus on gram staining (Photo by Md Atiqul Haque). Fig. 2: Bacillus cereus on MYPA (Photo by Hongkun Quan).

Table 2: Food poisoning outbreaks due to B. cereus worldwide from 2000 to 2020

\begin{tabular}{|c|c|c|c|c|c|c|c|}
\hline Year & $\begin{array}{l}\text { Country } \\
\text { /Region }\end{array}$ & Food & Affected persons/ consequences & $\begin{array}{l}\text { Contaminat } \\
\text { ion level } \\
(\mathrm{cfu} / \mathrm{g})\end{array}$ & $\begin{array}{l}\text { Attack } \\
\text { rate } \\
(\%)\end{array}$ & $\begin{array}{l}\text { Type of } \\
\text { poisoni } \\
\text { ng }\end{array}$ & Reference \\
\hline 2000 & Italy & Cakes & $\begin{array}{l}173 \text { people; } \mathrm{N} \text { and } \mathrm{D} \text { (watery), } 23 \\
\text { patients hospitalized }\end{array}$ & $10^{2}$ & n.a. & EPP & $\begin{array}{l}\text { Osimani et al. } \\
(2018)\end{array}$ \\
\hline \multirow[t]{2}{*}{2003} & Belgium & Pasta salad & $\begin{array}{l}\text { Family outbreak; } 5 \text { children } \\
\text { hospitalized; V, LF, } 1 \text { death }\end{array}$ & $\begin{array}{l}1.0 \times 10^{7} \\
-1.0 \times 10^{8}\end{array}$ & n.a & EP, EPP & $\begin{array}{l}\text { Dierick et al. } \\
(2005)\end{array}$ \\
\hline & Greece & No information & A 72-year-old woman, V, A, LF, death & $\begin{array}{l}\text { n.a. } \\
\text { n.a. }\end{array}$ & n.a & $\begin{array}{l}\text { EP } \\
\text { EP }\end{array}$ & $\begin{array}{l}\text { Latsios et al. } \\
(2003)\end{array}$ \\
\hline $\begin{array}{l}1991^{-} \\
2005\end{array}$ & Canada & $\begin{array}{l}\text { Mainly Asian food, } \\
\text { followed by raw food }\end{array}$ & 39 outbreaks, V, A, N and D & & 32 & & $\begin{array}{l}\text { McIntyre et al. } \\
(2008)\end{array}$ \\
\hline \multirow[t]{3}{*}{2005} & Spain & $\begin{array}{l}\text { Seafood cocktail and fried } \\
\text { shrimp }\end{array}$ & 100 people & $3.8 \times 10^{4}$ & 95 & $\begin{array}{l}\text { EP, EPP } \\
\text { EP, EPP }\end{array}$ & $\begin{array}{l}\text { Osimani et al. } \\
(2018)\end{array}$ \\
\hline & Finland & Pasta and meat dish & 2 persons; $\mathrm{V}$ and $\mathrm{D}$ & $1.3-1.8 \times 10^{5}$ & $\begin{array}{l}\text { n.a. } \\
\text { n.a. }\end{array}$ & & $\begin{array}{l}\text { Pirhonen et al. } \\
(2005)\end{array}$ \\
\hline & Korea & Cooked and fried rice & 37 persons; $\mathrm{V}, \mathrm{A}$ and headache & n.a. & n.a. & EP & Kim et al. (2010) \\
\hline $\begin{array}{l}2004^{-} \\
2006\end{array}$ & Korea & Not specified & Sporadic food poisoning case & n.a. & n.a. & $\begin{array}{l}\text { EP } \\
\text { EP }\end{array}$ & Chon et al. (2012) \\
\hline \multirow[t]{2}{*}{2006} & Germany & $\begin{array}{l}\text { Rice dish, cooked } \\
\text { cauliflower }\end{array}$ & $\begin{array}{l}18 \text { people ( } 17 \text { children, } 1 \text { adult), } V \text {, } \\
\text { collapsed with hospitalization }\end{array}$ & $1 \times 10^{4}$ & n.a & & $\begin{array}{l}\text { Osimani et al. } \\
(2018)\end{array}$ \\
\hline & Italy & Ricotta cheese & 57 persons & n.a. & & EPP & \\
\hline \multirow[t]{2}{*}{2007} & Germany & Ready-to-eat rice pudding & 46 people (43 children, 3 adults), V & n.a. & 30 & EP & \\
\hline & Spain & Cooked tuna fish & 5 persons, $\mathrm{G}$ & $8.0 \times 10^{6}$ & n.a. & EP & \\
\hline $\begin{array}{l}1998- \\
2008\end{array}$ & USA & $\begin{array}{l}\text { Rice, meat and poultry } \\
\text { dishes }\end{array}$ & $\begin{array}{l}235 \text { outbreak, } 2050 \text { people, } 17 \\
\text { hospitalizations, D, A,V }\end{array}$ & n.a. & n.a. & EP, EPP & $\begin{array}{l}\text { Haque et al. } \\
(2021)\end{array}$ \\
\hline $\begin{array}{l}2006- \\
2008\end{array}$ & India & Not specified & 42 case, $\mathrm{D}$ & $\begin{array}{l}\text { n.a. } \\
\text { n.a. }\end{array}$ & $\begin{array}{l}\text { n.a. } \\
\text { n.a. }\end{array}$ & EPP & $\begin{array}{l}\text { Banerjee et al. } \\
\text { (2011) }\end{array}$ \\
\hline \multirow[t]{6}{*}{2008} & France & Pasta & A 15-year-old boy; V, A, LF & n.a. & n.a. & EP & Saleh et al. (2012) \\
\hline & Belgium & Spaghetti meal (pasta) & A 20-year-old man; death & $\begin{array}{l}\text { n.a. } \\
\text { n.a. }\end{array}$ & & EP & $\begin{array}{l}\text { Naranjo et al. } \\
(2011)\end{array}$ \\
\hline & Oman & Hospital meal & $5^{8}$ people; $\mathrm{D}, \mathrm{V}$ & n.a. & 14.1 & EPP & $\begin{array}{l}\text { Al-Abri et al. } \\
(2011)\end{array}$ \\
\hline & $\begin{array}{l}\text { Switzerl } \\
\text { and }\end{array}$ & Pasta & A 9-year-old girl; A, V, LF, shock & $\begin{array}{l}\text { n.a. } \\
\text { n.a. }\end{array}$ & n.a. & EP & $\begin{array}{l}\text { Posfay-Barbe et } \\
\text { al. (2008) }\end{array}$ \\
\hline & Korea & Raw fish & 8 persons, family outbreak & n.a. & n.a. & EP, EPP & Kim et al. (2009) \\
\hline & Brazil & Fruits and vegetables & 93 cases, N, V, D, A & & n.a. & EP, EPP & Elias et al. (2018) \\
\hline 2009 & Brazil & Fruits and vegetables & 21 cases, 3 hospitalized, D, A & & n.a. & EP, EPP & \\
\hline \multirow[t]{3}{*}{2010} & Korea & Lunch buffet & 43 persons, $\mathrm{D}, \mathrm{A}$ & & 20.3 & EPP & Choi et al. 2011 \\
\hline & $\begin{array}{l}\text { German } \\
\text { y }\end{array}$ & Lunch buffet & 4 persons, acute $V$ & $\begin{array}{l}2.8 \times 10^{4} \\
\mathrm{CFU} / \mathrm{g}\end{array}$ & n.a. & EP & $\begin{array}{l}\text { Ehling-Schulz } \\
\text { and }\end{array}$ \\
\hline & Japan & Fried rice & An 11-year-old boy; G, LF, acute E, & $\begin{array}{l}\text { n.a. } \\
\text { n.a. }\end{array}$ & $\begin{array}{l}\text { n.a. } \\
\text { n.a. } \\
\text { n.a. }\end{array}$ & $\begin{array}{l}\mathrm{EP} \\
\mathrm{EP}\end{array}$ & $\begin{array}{l}\text { Messelhäusser } \\
\text { (2012) } \\
\text { Ichikawa et al. } \\
(2010)\end{array}$ \\
\hline
\end{tabular}


Japan Reheated fried rice

2011

German Mixed lunch (pasta)

y

Belgium Rice-based dishes

2008- France n.s.

2012

2012

Italy Basmati rice

UK Dried haricot beans

Belgium Mashed rice-cucumberchicory

2001- Australi Multiple foods

2013 a

2003- Brazil Mainly cereals, sauce

2013

2007- German Multiple foods

2013 y

2013 UK Ready-to-eat meat pie

Australi Buffet lunch

Austria Mashed potatoes Dish

Pancake strip soup

Fruit salad

2007- France Starchy food and

$2014 \quad$ Vegetables

2014 China Fermented black beans (douchi)

EMS Mixed food

2015 EMS Mixed food

Norway n.s.

Argenti Cooked chicken

na

German Rice meal

y

2016 France Human milk

USA Refried beans

2011- Korea n.s.

2017 USA n.s.

2017 Indones Sardines

ia

India Sweetened curd

2018 EMS n.s.

Australi Multi-course-dinner

a (Beef)

China School canteen food and drink

2019 German Buck wheat

$\mathrm{y}$

2020 China Breast milk (Taiwan )
3 persons; $V$, acute $E, 1$ death

22 persons (20 children, 2 adult), $4 \quad 2.2 \times 10^{6}$

hospitalized, acute D

$\mathrm{CFU} / \mathrm{g}$

8 people; 1 hospitalized

39 people, 8 death

12 people, $\mathrm{V}, \mathrm{N}, \mathrm{A}, \mathrm{D}$

200 people ( 182 children, 18 adults) $\mathrm{V}$

20 children, $\mathrm{V}$

6 outbreaks, 114 cases, 1 emetic and 5 diarrheal; V, D

346 people; 3 hospitalized, D, A, V n.a.

Several affected people, $\mathrm{V}$

5 people

125 people, $\mathrm{D}, \mathrm{A}$

14 people, 3 hospitalized

14 people

106 people

74 outbreaks, 911 cases, A,V, D

139 people, N, V, D

287 outbreaks, 3,073 cases, 257

hospitalized

291 outbreaks, 3131 cases, 101

hospitalized

4 outbreaks, 17 cases

A 39-year-old healthy woman,

hospitalized, V, D (watery)

A 13-month-old boy; V, A, LF

3 infant cases, hospitalized, sepsis,

brain hemorrhage, 2 death

179 people, V, D

$-3.4 \times 10^{5}$

n.a.

50 outbreak, 491 people

69 outbreak,1389 people

22 people, $\mathrm{V}, \mathrm{D}$

204 people, $A, V$

98 outbreak, 1539 people, 111

hospitalize, 1 death

15 people, $\mathrm{V}, \mathrm{D}$

209 people, $\mathrm{V}, \mathrm{D}, \mathrm{A}$, fatigue, dizziness, $10-1.6 \times 10^{5} 3.9-12.5 \mathrm{EPP}$

fever, headache

A 57-year-old woman; massive V, D,

esophageal perforation, Boerhaave

syndrome

A 1490-g female infant was

hospitalized, A, V, tachycardia,

hyperglycemia, and elevated C-reactive

protein
$2.8 \times 10^{5}$
$-2.4 \times 10^{7}$

n.a.

n.a.

$2.0 \times 10^{6}$

$>1.5 \times 10^{7}$

n.a.

$\leq 1 \times 10^{2}$

$-6.1 \times 10^{7}$

$1.5 \times 10^{6}$

$-1.0 \times 10^{8}$

n.a.

$2.1 \times 10^{5}$

$1.0 \times 10^{2}$

$-1.0 \times 10^{4}$

n.a.

$4.0 \times 10^{2}$

$-1.0 \times 10^{9}$

$1.6 \times 10^{7}$

$-2.3 \times 10^{7}$

n.a.

n.a.

n.a.

n.a.

n.a.

n.a.

n.a.

n.a.

n.a.

n.a.

n.a.

$3.5 \times 10^{3}$

$-1.9 \times 10^{4}$

Shiota et al.

(2010)

EPP

Ehling-Schulz

and

Messelhäusser

(2012)

EP Osimani et al.

EPP

(2018)

EP

63.2 EP

90.9 EP

n.a. EP, EPP May et al. (2016)

n.a.

n.a. EPP Lentz et al. (2018)

EP Messelhausser et

al. (2014)

EP McLauchlin et al.

(2016)

EPP Sloan-Gardner et al. (2014)

EP, EPP Osimani et al.

EP, EPP (2018)

EP, EPP

EP, EPP

EP,EPP

EP,EPP Zhou et al. (2014)

EP,EPP

EFSA and ECDC (2016)

n.a.

n.a.

n.a.

EP, EPP Lopez et al.

n.a.

n.a.

n.a.

n.a.

EP Tschiedel et al.

(2015)

EP, EPP Rigourd et

al .(2018)

EP,EPP Carroll et al (2019)

n.a. Kim and Kim

n.a. (2021)

EPP Depo et al. (2018)

EPP

Sahu et al. (2021)

44.0
n.a. EP, EPP Rodrigo et al.

EP, EPP 2021

Thirkell et al.

(2019)

Chen et al. (2019)

n.a. n.a. $\quad$ EP $\quad \begin{aligned} & \text { Dichtl et al. } \\ & (2019)\end{aligned}$

n.a. n.a

n.a Liao and Tsai (2020)

EMS= European member states; n.s.= Not specified; n.a.= Not available; N=Nausea; V= Vomiting; D=Diarrhea; A= Abdominal pain; $\mathrm{LF}=$ Liver failure; $\mathrm{E}=$ Encephalopathy, $\mathrm{G}=$ Gastroenteritis; $\mathrm{EP}=$ Emetic poisoning; $\mathrm{EPP}=$ Enteropathgenic poisoning 
Bacillus spp. as probiotics/feed additives, food safety implication and antibiotic resistance

Strains of Bacillus species have long been used as probiotics in human, veterinary, aquaculture, plant and environmental applications. Probiotic strains are used in animal production, either directly as microbial feed additives, or as a source of other feed additives, especially enzymes (EFSA 2011; Cui et al. 2019). Spores of Bacillus strains are used in human, veterinary, and aquaculture applications due to their probiotics characteristics, and the bacteria can then spread in food after ingestion (Carlin and Nguyen-The 2013). Bacillus-based probiotics can have a beneficial impact on poultry production by strongly activating immune-related components, controlling pathogenic bacteria, modulating immune responses, fostering gut integrity, raising feed conversion rate (FCR), acting as a growth factor and improving disease resistance and health (Bilal et al. 2020; Arsene et al. 2021). B. subtilis is a common food supplement in animal industry, particularly in poultry and fish farming (Arsene et al. 2021). In the swine industry, it is used as a replacement for antibiotics to treat diarrhea in weaning piglets; Bacillus spp.-fermented (notably B. subtilis, B. licheniformis, B. amyloliquefaciens) feed additives have been found to reduce morbidity and mortality rates, ameliorate enteritis, have a beneficial impact on the lessening diarrheal incidence and increasing the growth efficiency of weaning piglets (Lin and $\mathrm{Yu}$ 2020; Arsene et al. 2021). However, some bacteria of $B$. cereus and other group may cause problems by producing different enterotoxins and emetic toxins (Table 5), and carrying ARG, which can be transmitted to humans via the food chain or the environment. In light of the data about the above noted probiotic candidates, especially those belonging to the $B$. cereus group, it appears that they have no toxic potential (Cui et al. 2019).

Antibiotics are a common way to control or prevent bacterial infections in farming, and the widespread use of antibiotic growth promoters (AGP) in animal feed has led to a rise in livestock production. However, inappropriate and abusive antibiotics use can spread antibiotic residues in animal-derived foods, such as milk, meat, and eggs, as well as the environment, might spread antibiotic resistance in animal microbial communities, with the possibility of ARG being transferred from animal to human microbiota (Mingmongkolchai and Panbangred 2018; Arsene et al. 2021). Resistance determinants for $\beta$ lactams (bla $\left.a_{B C L-1}\right), \quad$ chloramphenicol (cat $\left.{ }_{B c l}\right)$, aminoglycosides ( $a a d D_{2}$ ), macrolides (erm34), tetracycline (tet $M$ and tet $K$ ) and erythromycin (ermD and ermK) have been found in probiotic strains of B. cereus, B. clausii, $B$. subtilis and $B$. licheniformis (Mingmongkolchai and Panbangred 2018). Consequently, global public health authorities have raised concerns about AGP and their role in the increased multidrug-resistant bacteria, with adverse effects on consumer health (Mingmongkolchai and Panbangred 2018; Arsene et al. 2021). Since the use of antibiotics in animal feeds has been banned in several countries, an alternative approach that has proved useful is the application of probiotics in consideration of the safety evaluation of new probiotics. Fig. 5 depicts the main route of transmission and development of antibiotic resistance from the feed and food chain to humans.

\section{Isolation and Identification}

$B$. cereus can be isolated and identified from food and other samples, using a variety of methods. Table 6 displays the advantages and limitations of various such approaches.

\section{Traditional Approaches}

$B$. cereus isolation and enumeration from foods, environment and clinical settings are usually done with conventional selective plating media. Food authorities suggest two standard media for $B$. cereus identification: Mannitol-egg yolk-polymyxin agar (MYPA) and Polymyxin-egg yolk-mannitol-bromothymol blue (PEMBA) for their characteristic colonies, Pink color and Peacock blue color precipitation zones of egg yolk hydrolysis, respectively (Figs. 2 and 3). Finally, to distinguish hemolytic and nonhemolytic $B$. cereus strains, a hemolysis test is conducted on $5 \%$ sheep blood agar plates at $37^{\circ} \mathrm{C}$, which produces dull gray and opaque colonies with a rough matted surface (Fig. 4) (Eglezos and Dykes 2014; Pontieri 2016; Griffiths and Schraft 2017; Ramarao et al. 2020; Haque et al. 2021). Several biochemical and microscopic tests are performed after bacterial isolation, including glucose, mannitol, xylose, arabinose, oxidase, motility, catalase, citrate utilization, casein hydrolysis, nitrate reduction, Voges-Proskauer (VP) reaction, l-tyrosine reduction, and growth in $0.001 \%$ lysozyme to validate and distinguish various phylogenetically close Bacillus spp. (Table 7). The miniaturized API $50 \mathrm{CHB}$ test package (bioMerieux), which evaluates the capacity to assimilate 49 carbohydrates, is a quick Bacillus identification method based on conventional biochemical tests. This system is believed to be capable of classifying possible emetic strains, but it does not distinguish $B$. cereus and $B$. thuringiensis (Eglezos and Dykes 2014; Griffiths and Schraft 2017).

\section{Molecular Methods}

Molecular approaches for confirming Bacillus spp. identification include a variety of techniques, which are summarized in Fig 6. Genes encoding major enterotoxins (nhe, hbl, cytK, entFM, bceT, hlyII) and emetic toxin (cesA, cesB) at various levels of production are much more relevant with respect to species determination (Table 8) in $B$. cereus toxin gene profiling by PCR detection protocols, particularly in outbreak situations. Furthermore, diagnostics should focus more on determining toxin or virulence genes, as well as toxin output quantification (Pontieri 2016; Ramarao et al. 2020). PFGE is one of the most effective fingerprint typing methods for $B$. cereus outbreak in the epidemiological investigation, because it splits large pieces of genomic DNA and allows for precise 
Table 3: Incidence of B. cereus food poisoning in different foods worldwide from 2000 to 2020

\begin{tabular}{|c|c|c|c|c|}
\hline Year & Country/Region & Food & Incidence (\%) & Reference \\
\hline \multirow[t]{2}{*}{$1998-2000$} & Germany & Mass catering food & 60 & Ehling-Schulz and Messelhäusser (2012) \\
\hline & France & n.s. & $4-5$ & Tewari and Abdullah (2015) \\
\hline 2000 & Norway & n.s. & 32 & Haque et al. (2021) \\
\hline 2001-2002 & Turkey & Meat and meat products & 22.4 & Tewari and Abdullah (2015) \\
\hline \multirow[t]{2}{*}{2003} & Czech Republic & Dairy products & 31.0 & Schlegelova et al. (2003) \\
\hline & & Meat products & 28.0 & \\
\hline 2004 & USA & Retail chicken products & 45.0 & Smith et al. (2004) \\
\hline $1991-2005$ & China (Taiwan) & n.s & 11.2 & Raddadi et al. (2010) \\
\hline \multirow[t]{3}{*}{2005} & Spain & Seafood cocktail and fried shrimp & 5.0 & Hernandoa et al. (2007) \\
\hline & India & Milk and milk products & 53.8 & Tewari and Abdullah (2015) \\
\hline & Chile & Dried milk products & 45.9 & Kumari and Sarkar (2016) \\
\hline \multirow[t]{2}{*}{2006} & Netherland & n.s. & 5.4 & Haque et al. (2021) \\
\hline & China & Pasteurized full-fat milk & 71.0 & Kumari and Sarkar (2016) \\
\hline \multirow[t]{2}{*}{ 2006-2007 } & Australia & Chilled raw diced chicken & 2.4 & Haque et al. (2021)) \\
\hline & USA & Raw rice & 46.6 & Ankolekar et al. (2009) \\
\hline \multirow[t]{2}{*}{2007} & EU & Not specified & 17.1 & Tewari and Abdullah (2015) \\
\hline & Belgium & Commercial food products & 56.3 & Samapundo et al. (2011) \\
\hline 1998-2008 & USA & Rice, meat and poultry dishes & 19.0 & Haque et al. (2021) \\
\hline 2001-2008 & Korea & Raw fish & $3 \cdot 7$ & Chon et al. (2012) \\
\hline \multirow[t]{2}{*}{ 2006-2008 } & India & n.s. & 3.5 & Banerjee et al. (2011) \\
\hline & Korea & Cooked rice & 37.5 & Chang et al. (2011) \\
\hline \multirow[t]{2}{*}{2008} & Turkey & Cheese & 12.0 & Kumari and Sarkar (2016) \\
\hline & Austria & Ice cream & 62.7 & Heydarzadeh et al. (2020) \\
\hline 2007-2009 & Korea & n.s. & 1.5 & Gwack et al. (2010) \\
\hline \multirow[t]{4}{*}{$2008-2009$} & Germany & Marinated pork products & 21.0 & Haque et al. (2021) \\
\hline & Jordan & Various foods & 23.3 & Batchoun et al. (2011) \\
\hline & Korea & Brown rice and glutinous rice & 37.0 & Lutpiatina (2020) \\
\hline & Turkey & Milk and meat products, Boza & 66.0 & Güven and Mutlu 2009 \\
\hline \multirow[t]{2}{*}{2009} & India & Traditional food & 46.0 & Tewari and Abdullah (2015) \\
\hline & Egypt & Raw milk & 30.0 & Kumari and Sarkar (2016) \\
\hline 2009-2010 & USA & Raw commingled silo milk & 8.9 & Liu et al. (2020) \\
\hline 2010 & Scotland & Cheese & 32.0 & Heydarzadeh et al. (2020) \\
\hline 2011 & Belgium & Cooked rice & 18.5 & Delbrassinne et al. (2012) \\
\hline \multirow[t]{2}{*}{ 2010-2012 } & Korea & Fermented soybean products & 67.9 & Kim et al. (2015) \\
\hline & Brazil & Milk and dairy products & 24.2 & Heydarzadeh et al. (2020) \\
\hline \multirow[t]{3}{*}{2012} & Mexico & Vegetables & 57.0 & Flores-Urban et al. (2014) \\
\hline & India & Meat and meat products & 30.8 & Tewari et al. (2012) \\
\hline & & Raw milk & 11.0 & \\
\hline $2003-2013$ & Brazil & Cereals or sauces & 3.1 & Haque et al. (2021) \\
\hline $2007-2013$ & Germany & Multiple foods & 10.0 & Messelhausser et al. (2014) \\
\hline $2012-2013$ & Singapore & Sushi & 5.1 & Yap et al. (2019) \\
\hline 2013 & Iran & Infant food & 42.0 & Lutpiatina (2020) \\
\hline $2007-2014$ & EU & n.s. & 27.6 & Haque et al. (2021) \\
\hline 2008-2014 & Brazil & Fruits and Vegetables & 6.6 & Elias et al. (2018) \\
\hline \multirow[t]{4}{*}{$2013-2014$} & China & Raw milk & 9.8 & Cui et al. (2016) \\
\hline & Iran & Powdered milk infant formula & 67.2 & Dallal et al. (2017) \\
\hline & Iran & Beef Burger & 31.2 & Soleimani et al. (2017) \\
\hline & EU & Not specified & $5 \cdot 5$ & Food safety authority of Ireland (2016) \\
\hline \multirow[t]{5}{*}{2014} & India & Various dairy products & 32.0 & Kumari and Sarkar (2016) \\
\hline & Cambodia & Fermented vegetables & 31.0 & Chrun et al. (2017) \\
\hline & Malaysia & Formula milk & 41.7 & Lesley et al. (2017) \\
\hline & & UHT milk & 30.0 & \\
\hline & China & Infant formula & 3.5 & Zhang et al. (2017) \\
\hline $2013-2015$ & & Rice flour & 1.0 & \\
\hline & Nigeria & Retailed foods & 36.8 & Adesetan et al. (2019) \\
\hline 2014-2015 & Canada & Pasteurized Fluid Milk & $5 \cdot 5$ & Saleh-Lakha et al. (2017) \\
\hline & Italy & Dairy products & 26.8 & Haque et al. (2021) \\
\hline & Egypt & Meat products & 43.7 & Mohamed and Ghanyem (2015) \\
\hline 2015 & Ghana & Raw milk & 46.6 & Heydarzadeh et al. (2020) \\
\hline & Nigeria & Milk-based infant food & 3.0 & Ranjbar and Shahreza (2017) \\
\hline & Korea & RTE vegetables & 48.0 & Chon et al. (2015) \\
\hline & Iran & Raw and cooked meat & 14.5 & Zeighami et al. (2020) \\
\hline $2002-2016$ & Italy & Ricotta cheese & $15 \cdot 9$ & Scatassa et al. (2018) \\
\hline & & Retail aquatic products & 25.4 & Zhang et al. (2020) \\
\hline
\end{tabular}




\begin{tabular}{|c|c|c|c|c|}
\hline \multirow{4}{*}{ 2011-2016 } & \multirow{3}{*}{ China } & Pasteurized milk & 27.0 & Liu et al. (2020) \\
\hline & & Meat and meat products & 26.3 & Kong et al. (2021) \\
\hline & & Vegetables & 50.0 & Yu et al. (2019) \\
\hline & & RTE foods & 35.0 & Yu et al. (2020) \\
\hline \multirow{3}{*}{2016} & China & Goat milk powder infant formula & 36.1 & Liu et al. (2018) \\
\hline & Brazil & Pasteurized Milk & 28.6 & Chaves et al. (2017) \\
\hline & Mexico & Artisan cheeses & 29.4 & Adame-Gomez et al. (2020) \\
\hline 2007-2017 & Poland & Commercial food products & 38.8 & Berthold-Pluta et al. (2019) \\
\hline \multirow[t]{2}{*}{ 2011-2017 } & Korea & n.s. & 6.5 & Kim and Kim (2021) \\
\hline & USA & $\begin{array}{l}\text { n.s. } \\
\text { Boiled milk }\end{array}$ & $\begin{array}{l}3 \cdot 5 \\
50.0\end{array}$ & \\
\hline \multirow[t]{4}{*}{2017} & Egypt & Pasteurized milk & 15.0 & Abou Zeid and Yassin (2017) \\
\hline & & UHT milk & 15.0 & \\
\hline & & Beef products & 26.0 & Shawish and Tarabees (2017) \\
\hline & Turkey & Milk and cheese & 10.4 & Yibar et al. (2017) \\
\hline \multirow[t]{3}{*}{$2017-2018$} & Malaysia & Ready-to eat cooked rice & 34.0 & Navaneethan and Esah (2020) \\
\hline & China & Raw milk & 16.0 & Liu et al. (2020) \\
\hline & Switzerland & PIF & 78.0 & Heini et al. (2018) \\
\hline \multirow[t]{3}{*}{2018} & China & School canteen food and drink & 4.1 & Chen et al. (2019) \\
\hline & EU & n.s. & 1.9 & Rodrigo et al. (2021) \\
\hline & Thailand & Mixed food stuffs & 21.0 & Sornchuer and Tiengtip (2021) \\
\hline \multirow[t]{3}{*}{ 2018-2019 } & China & Dairy products & 10.8 & Liu et al. (2020) \\
\hline & Iran & Dairy products & 10.6 & Heydarzadeh et al. (2020) \\
\hline & Egypt & Buffalo milk & 12.9 & Abouelhag et al. (2021) \\
\hline \multirow[t]{2}{*}{2019} & Italy & Fried rice meals & 7.8 & Tirlonia et al. (2019) \\
\hline & Indonesia & Cooked rice (yellow rice) & 21.0 & \\
\hline \multirow[t]{4}{*}{$2019-2020$} & Iraq & Soft cheese & 67.0 & Al-Jobory and Abdulaal (2020) \\
\hline & Egypt & Various RTE food & 5.0-10.0 & Enan et al. (2020) \\
\hline & & Milk powder & 6.9 & Abdeen et al. (2020) \\
\hline & Egypt & Ras-cheese & 8.5 & \\
\hline \multirow[t]{5}{*}{2020} & & Meat and Chicken Products & 21.5 & Gharib et al. (2020) \\
\hline & Pakistan & Different milk & 20.0 & Rafique et al. (2020) \\
\hline & Malaysia & UHT chocolate milk & $24 \cdot 3$ & Ubong et al. (2020) \\
\hline & China & Rice/ noodles & 50.0 & Lutpiatina (2020) \\
\hline & Colombia & Powdered food & 11.0 & Sanchez-Chica et al. (2020) \\
\hline
\end{tabular}

n.s.= Not specified; RTE $=$ Ready to eat; PIF=Powdered infant formula; UHT= Ultra heat treatment.

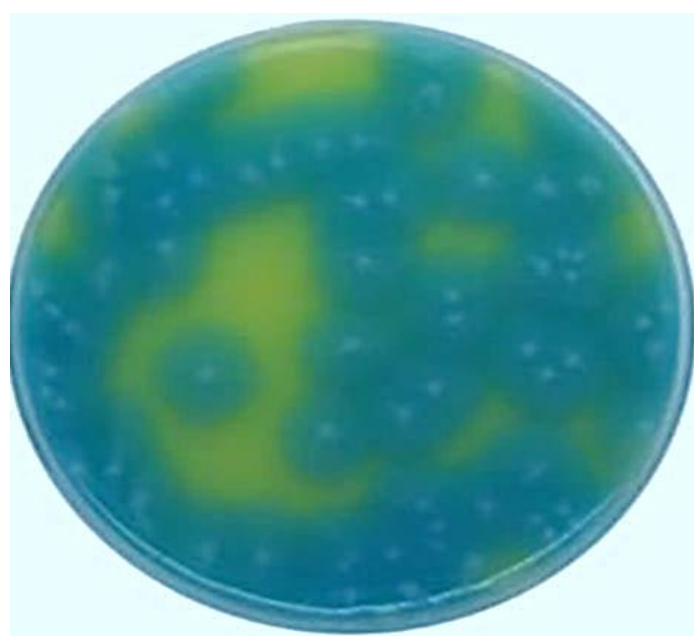

Fig 3: Bacillus cereus on PYMBA (Photo by Md Atiqul Haque).

resolution of minor variations in genomic sequences for bacterial group studies. The RAPD-PCR method is a reliable and widely used for molecular typing of diverse Bacillus spp; it uses specific primers to randomly amplify segments of target DNA. It can be used to distinguish emetic strains from other $B$. cereus strains and is thus commonly shown in the laboratory as a screening process. MLST is considered the "gold standard" for

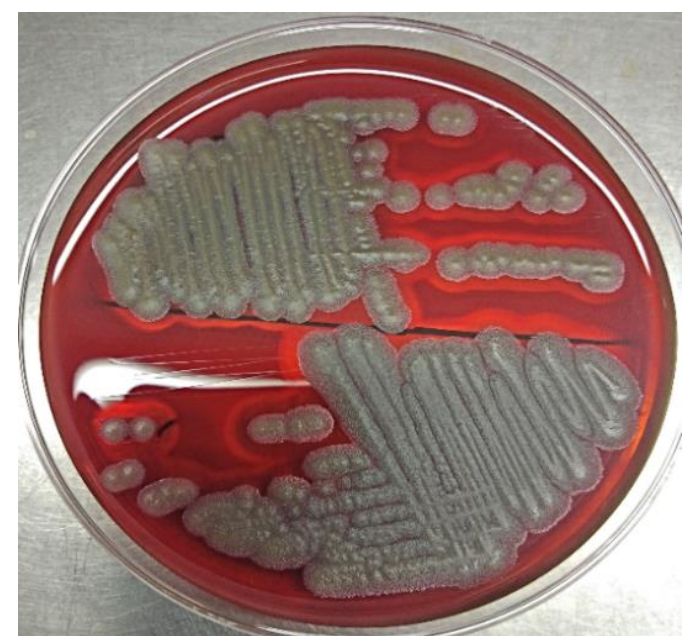

Fig. 4: Bacillus cereus on Blood agar (Photo by Hongkun Quan).

typing of $B$. cereus group strains, showing the sequences of many basic or housekeeping genes clustered across the chromosomes, occurring in three major Bacillus spp. clades.

For certain applications, AFLP may be preferable to classify various $B$. cereus strains into different phylogenetic classes (Pontieri 2016; Griffiths and Schraft 2017; Grutsch et al. 2018). 


\section{Spectrometry}

MALDI-TOF-MS has been widely adopted and applied in clinical microbiology for routine pathogen detection at the species level. The mass/charge ratio of microbial proteins ionized from intact cells collected from pure culture is graphed as a peak in mass spectrometry results. The mass spectral profile is defined by comparing it to a reference database. MALDI-TOF-MS was used to detect enterotoxins ( $\mathrm{CytK} 1$ and Nhe) produced by pathogenic strains and was found to be an effective risk assessment technique in routine pathogen detection for determining the presence of $B$. cereus strains in food-borne outbreaks (Pontieri 2016).

\section{Biosensors}

Biosensors have proven to be effective in detecting foodborne pathogens, such as $B$. cereus. Several biosensorsbased techniques for detecting $B$. cereus have been developed and published so far. DNA-based biosensors, in particular, have shown a great success because they allow for the selective identification of different $B$. cereus strains. As an alternative to DNA probes, mono or polyclonal antibodies targeting $B$. cereus cells can be used as identification elements in biosensors (Ramarao et al. 2020).

A biosensor incorporates rabbit polyclonal anti- $B$. cereus antibodies that have been shown to have high sensitivity, detecting $B$. cereus at concentrations as low as $10^{1} \mathrm{CFU} / \mathrm{ml}$, and rapidity with a detection period of just 6 minutes (Raddadi et al. 2010).

\section{Detection and Quantification of toxins}

\section{Detection and Quantification of Cereulide (Ces)}

For the detection and quantification of cereulide (Ces) toxin in various food matrixes, a variety of assays are now available. Generally, cell culture-based assays, using various cell lines (HEp-2, Hep-G2, CaCo-2, HeLA cells), and sperm-based assays in which the biological effects of Ces can be assessed by inhibition of mitochondrial function, cellular vacuolization and loss of motility of boar spermatozoa, have been used. These assays, however, are not so precise, since other mitochondrial toxins are also susceptible to them and impair sperm motility (Raddadi et al. 2010; Cui et al. 2019). Instrumental methods, such as high-performance liquid chromatography (HPLC), HPLC linked to ion trap mass spectrometry (HPLC-MS), and matrix-assisted laser desorption ionization time-of-flight mass spectrometry (MALDI-TOF-MS) are used to detect Ces toxin (Cui et al. 2019). A new reversed - phase chromatography (RPC) was developed recently to identify and quantitatively measure Ces toxin existence, using ultra performance liquid chromatography-mass spectrometry (UPLC-MS/MS) (Kalbhenn et al. 2021).

\section{Detection and Quantification of Enterotoxins (Nhe, $\mathrm{Hbl}$, and CytK)}

Various tests, such as the vascular permeability reaction (VPR), the ligated rabbit ileal loop, and cell cytotoxicity assays, are currently available and widely used for the detection of diarrheal toxins (Raddadi et al. 2010). VPR

Table 4: Main features of food-borne diseases associated with $B$. cereus

\begin{tabular}{|c|c|c|c|}
\hline Properties & Diarrheal syndrome & Emetic syndrome & Reference \\
\hline Type & Toxico-infection & Intoxication & Raddadi et al. \\
\hline Mode of action & $\begin{array}{l}\text { Receptor unknown, however Hbl, Nhe and Cytk } \\
\text { specific receptors are suggested; causes hemolysis, } \\
\text { cytolysis, demonecrosis and vascular permeability } \\
\text { activity }\end{array}$ & $\begin{array}{l}\text { Binds to serotonin } 5 \text {-HT3 receptors; causes emesis } \\
\text { by action on vagus afferent, inhibition of } \\
\text { mitochondrial fatty acid oxidation and } \mathrm{T}(\mathrm{NK}) \text { cells }\end{array}$ & $\begin{array}{l}\text { (2010), } \\
\text { Lindbäck and } \\
\text { Granum } \\
\text { (2019), }\end{array}$ \\
\hline Regulatory gene & PlcR & SpooA and AbrB & Kumari and \\
\hline Infective dose & $10^{5}-10^{7}$ cells (total) or cfu/g & $\begin{array}{l}10^{5}-10^{8} \text { cells (per g/ml substrate) or } 0.02-1.83 \mu \\
\mathrm{g} / \mathrm{kg} \text { of body weight }\end{array}$ & $\begin{array}{l}\text { Sarkar (2016), } \\
\text { Griffiths and }\end{array}$ \\
\hline $\begin{array}{l}\text { Toxin } \\
\text { production }\end{array}$ & In the small intestine of the host & Preformed in foods & $\begin{array}{l}\text { Schraft (2017), } \\
\text { Lindbäck and }\end{array}$ \\
\hline Toxin involve & Cereulide & Hbl, Nhe and CytK & Granum \\
\hline Nature of toxin & $\operatorname{Protein}(\mathrm{s})$ & Cyclic peptide & (2019) \\
\hline Heat stability & Labile, inactivated $5^{\circ} \mathrm{C}, 5 \mathrm{~min}$ & Extremely stable $121^{\circ} \mathrm{C}, 90 \mathrm{~min}$ & \\
\hline pH stability & Unstable $<4$ and $>11$ & Stable 2- 11 & \\
\hline $\begin{array}{l}\text { Requirements } \\
\text { for illness }\end{array}$ & $\begin{array}{l}\text { Vegetative cells of spore production in food to an } \\
\text { infectious dose, consumption of which leads to } \\
\text { infection and formation of toxins inside of a host }\end{array}$ & $\begin{array}{l}\text { Cereulide production in food at high concentration } \\
\text { outside of host resulting illness due to } \\
\text { consumption of pre-formed toxin }\end{array}$ & \\
\hline Incubation time & $8-16$ h (occasionally $>24 \mathrm{~h}$ ) & $0.5^{-6 h}$ & \\
\hline $\begin{array}{l}\text { Duration of } \\
\text { illness }\end{array}$ & 12-24 h (occasionally $>24 \mathrm{~h}$ ) & $6-24 \mathrm{~h}$ & \\
\hline Symptoms & $\begin{array}{l}\text { Abdominal pain, watery diarrhea (occasionally } \\
\text { bloody type), sometimes with nausea and lethality }\end{array}$ & $\begin{array}{l}\text { Nausea, vomiting, malaise (sometimes followed by } \\
\text { diarrhea), in some cases fatal liver failure }\end{array}$ & \\
\hline $\begin{array}{l}\text { Foods } \\
\text { commonly } \\
\text { implicated }\end{array}$ & $\begin{array}{l}\text { Proteinaceous foods: meat products, fish, poultry, } \\
\text { soups, vegetables, puddings, sauces and stews, } \\
\text { milk and milk products }\end{array}$ & $\begin{array}{l}\text { Farinaceous/Starch-rich foods; fried and cooked } \\
\text { rice, pasta, potatoes, bread, pastries and noodles }\end{array}$ & \\
\hline $\begin{array}{l}\text { Assays available } \\
\text { for detection }\end{array}$ & $\begin{array}{l}\text { Hep-2 cell bioassay, rapid sperm bioassay, HPLC- } \\
\text { MS and PCR-based assays }\end{array}$ & $\begin{array}{l}\text { BCET-RPLA, Tecra BDE-VIA kit, and Duopath } \\
\text { Cereus Enterotoxins test assay }\end{array}$ & \\
\hline
\end{tabular}




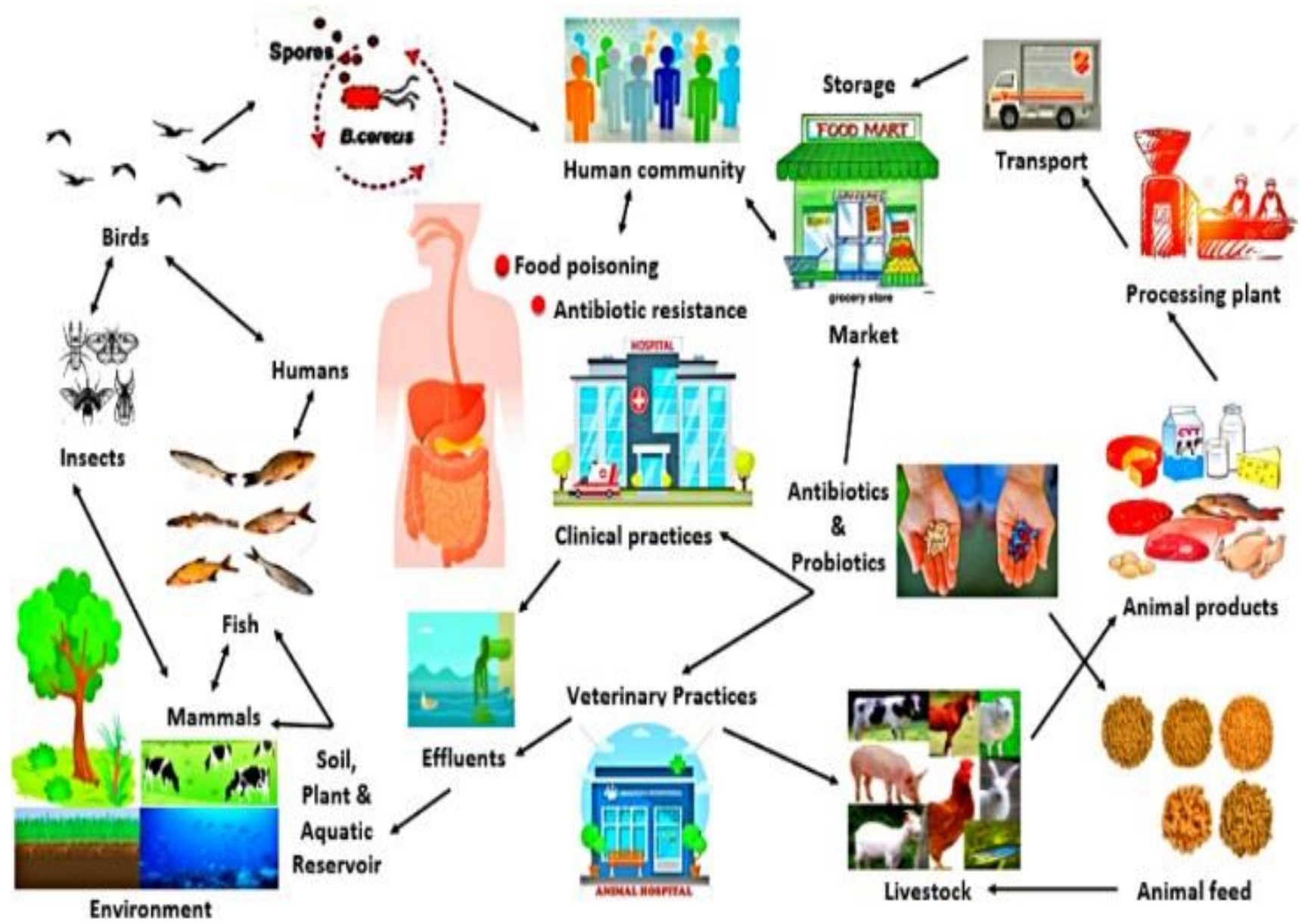

Fig 5: Flowchart showing the presence of antibiotic residues arising from the use of probiotic and antibiotic in animal feed (Arsene et al. 2021; Haque et al. 2021; Hassan et al. 2021).

Table 5: Bacillus spp. implicated in food-borne infections and the related toxins

\begin{tabular}{|c|c|c|c|}
\hline Species & Toxins & Features & References \\
\hline B. thuringiensis & Enterotoxins & Heat-labile, cytotoxicity, risk of food-borne intoxication implicated & Griffiths (2010); \\
\hline & Cereulide & Heat-stable, risk of food-borne intoxication implicated & EFSA (2011); \\
\hline \multicolumn{3}{|l|}{ weihenstaphanensis } & Delbrassinne and \\
\hline B. subtilis & $\begin{array}{l}\text { Amylolysin, } \\
\text { fengycin }\end{array}$ & $\begin{array}{l}\text { Surfactin-like components, heat-stable, inhibition of boar sperm motility, } \\
\text { cytotoxicity, implicated in food-borne gastroenteritis }\end{array}$ & $\begin{array}{l}\text { Mahillon (2016); } \\
\text { Mingmongkolchai }\end{array}$ \\
\hline B. licheniformis & Lichenysins & $\begin{array}{l}\text { Heat-stable lipopeptide, inhibition of boar sperm motility, implicated in } \\
\text { food-borne gastroenteritis, fatal cases reported (dairy and infant food), } \\
\text { also involved in local and systemic infections }\end{array}$ & $\begin{array}{l}\text { and Panbangred } \\
(2018) ; \text { Haque et al. } \\
(2021) ;\end{array}$ \\
\hline B. pumilus & Pumilacidins & $\begin{array}{l}\text { Complex lipopeptides, heat-stable, inhibition of boar sperm motility, } \\
\text { implicated in food-borne poisoning, also involved in local and systemic } \\
\text { infections }\end{array}$ & \\
\hline B. fusiformis & Cytotoxins & Lipopeptides; heat-stable, cytotoxicity & \\
\hline B. mojavensis & $\begin{array}{l}\text { Amylolysin, } \\
\text { fengycin }\end{array}$ & $\begin{array}{l}\text { Surfactin-like components, heat-stable, cytotoxicity, inhibition of boar } \\
\text { spermatozoa motility, implicated in food-borne poisoning }\end{array}$ & \\
\hline $\begin{array}{l}\text { B. } \\
\text { amyloliquefaciens }\end{array}$ & Amylosin & Heat-stable lipopeptide, connected with food poisoning & \\
\hline B. firmus & $\begin{array}{l}\text { Cereulide-like } \\
\text { toxins }\end{array}$ & Lipopeptides; heat-stable, inhibition of boar sperm motility & \\
\hline B. simplex & $\begin{array}{l}\text { Cereulide-like } \\
\text { toxins }\end{array}$ & Lipopeptides; heat-stable, inhibition of boar sperm motility & \\
\hline B. circulans & Cytotoxins & $\begin{array}{l}\text { Implicated in food-borne poisoning, also involved in local and systemic } \\
\text { infections }\end{array}$ & \\
\hline B. lentus & Cytotoxins & Toxin production observed, but no food poisoning case reported yet & \\
\hline B. megaterium & $\begin{array}{l}\text { Cereulide-like } \\
\text { toxins }\end{array}$ & Lipopeptides, implicated in food-borne poisoning & \\
\hline
\end{tabular}




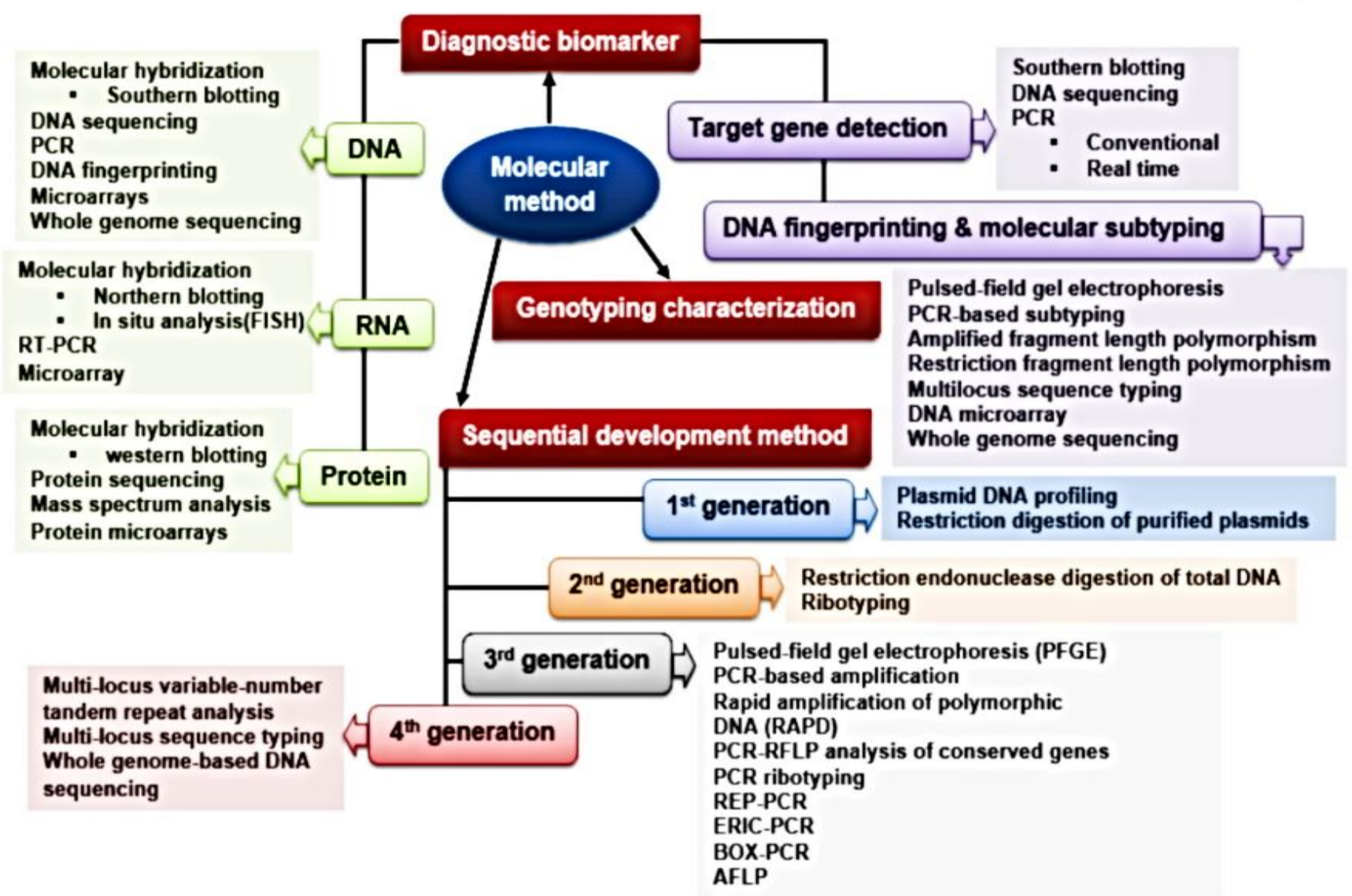

Fig. 6: Molecular methods for the isolation and identification of bacteria (Raddadi et al. 2010; Quinn et al. 2016).

Table 6: Advantages and disadvantages of different diagnostic methods

\begin{tabular}{|c|c|c|}
\hline Methods & & Advantages \\
\hline $\begin{array}{l}\text { Traditional } \\
\text { method }\end{array}$ & $\begin{array}{l}\text { Culture medium- } \\
\text { based method and } \\
\text { microscopic } \\
\text { observation with } \\
\text { Biochemical assay }\end{array}$ & $\begin{array}{l}\text { Simple, cheap and easy handling } \\
\text { Able to recognize a single bacterial } \\
\text { strain } \\
\text { Identification of viable cells } \\
\text { Optimal toward suitable media } \\
\text { For phenotypic drug susceptibility } \\
\text { testing } \\
\text { Inexpensive equipment }\end{array}$ \\
\hline
\end{tabular}

Immunological ELISA, RPLA and Precise and reproducible results method

Molecular immunofluorescence Inexpensive equipment assay

Onsite application

method
PCR

Highly accurate

Relatively high sensitivity and specificity
Real-time PCR

Disadvantages
Time-consuming, laborious and resource
demand
Poor sensitivity and specificity
Not possible to detect injured or VBNC
cells
Can lead to misidentification
Risk of contamination
Require qualified personnel
Relatively low sensitivity and selectivity/
specificity Immunodeficient host may not
be able to respond

Not real-time

Not able to distinguish dead and alive cells Kim and Kim

Not for qualification (2020);

Sophisticated, expensive equipment and Mishra et al. costly

Sometimes amplification errors or false- Ramarao et negative results

al. (2020);

Require enrichment step in case of a lower Vidic et al. number of pathogens

Gel electrophoresis is laborious, time-

consuming and low-resolution

(2020);

Kalbhenn et

al. (2021)

False-positive results due to laboratory contamination.

Not real-time

Not able to distinguish dead and alive cells Require enrichment step in case of a lower number of contaminants

Risk of contamination with genomic DNA Possibility of false-positive results 
Multiplex PCR

Nested PCR

ERIC- PCR

RAPD

AFLP

RFLP

MLST

NGS

PFGE

LMAP

CAMP

Hybridization

DNA microarray

Spectrometry MALDI-TOF-MS and

chromatographic

method LC-MS

SIDA-MS/MS

RPC

Biosensors

Gold nanoparticle (AuNPs) aggregation
Detection of multiple pathogens or toxins simultaneously Small quantities of DNA extracted Economic and time saving

High sensitivity and specificity Decreases non-specific target sequence amplification

Highly reliable

Easy and first

Inexpensive

Very simple and fast Inexpensive

Strongly distinguishable Sensitive and specific

High resolution and sampling power Reproducibility

Strong discrimination and typification

Clarity

Rapid tool for large population analysis

Repeatable and indisputable

Fully automated analysis

Highly accurate

Quantitative

Detection of multiple pathogens in one sample

Stability,

Reproducibility

More discriminatory

Highly accurate

High specificity and sensitivity

Rapid, simple and efficient

Without expensive equipment and complicated thermo-cycling

Highly accurate

Relatively more rapid, specific and sensitive

Easy, reliable and simpler primer design

High sensitivity and specificity

Low cost

Fast detection

High efficiency

Multiple genes analysis

Highly accurate

Fast, easy and reliable

Cost-effectiveness

Highly accurate

Highly accurate

Fast, easy and robust

Cost-effective

Onsite application

Easy, rapid and detection by the naked eye
Genetic heterogeneity detection

Intrusion by the existence of

polymorphism

Possibility of false-negative results

Only qualitative, not for quantification

Further confirmation test is required

Costly and time-consuming

Risk of cross-contamination

Low discrimination

Extremely laboratory-based

Requires carefully designed laboratory protocols for reproduction

Costly

More reaction phage and reagents

Lower sensitivity for specific mutant

Laborious and time-consuming

Expensive

Requires intensive sequencing efforts

Expensive

Not real-time

Required bioinformatics analysis

Time-consuming

Expensive

Labor intensive

Strict primer design principle

Possibility of false-positive results

Possibility of false-positive results

Costly and time-consuming

Focused on DNA assay

Confounding first time users

Findings are not reproducible

Pure cultures are needed

Quantification error

Expensive MS equipment required

Sophisticated and expensive high-end MS

equipment required

Require trained personnel

Costly and relatively low affinity

Not easy to apply in solid or liquid-solid

matrix

VBNC=Viable but not-culturable; PCR=Polymerase chain reaction; ERIC-PCR=Enterobacterial Repetitive Intergenic Consensus-PCR; ELISA=Enzyme-linked immunosorbent assay; RPLA=Reverse passive latex agglutination; LMAP=Loop-mediated isothermal

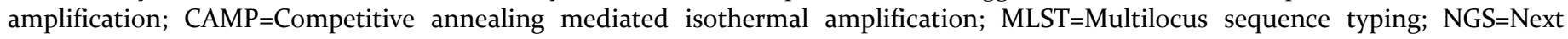
generation sequencing; MALDI-TOF-MS=Matrix-assisted laser desorption ionization time-of-flight mass spectrometry; LC-MS=Liquid chromatography coupled to mass spectrometry; SIDA-MS/MS=Stable isotope dilution assay tandem mass spectrometry; $\mathrm{RPC}=$ Reversed-phase chromatography; RAPD=Random amplified polymorphic DNA; AFLP=Amplified fragment length polymorphism; $\mathrm{RFLP}=$ Restriction fragment length polymorphisms; PFGE= Pulsed-field gel electrophoresis. 
Table 7: Phenotypic criteria to differentiate members of the $B$. cereus group

\begin{tabular}{|c|c|c|c|c|c|c|c|c|c|}
\hline Features & $B$. & B. & B. & B. & B. & $B$. & $B$. & $B$. & References \\
\hline & & & thuringiensis & mycoides & udomycoi & nstepan & ytoticus & oyonesis $^{d}$ & \\
\hline Gram stain & + & + & + & + & + & + & + & + & Fritze and \\
\hline Colony morphology & White & White & White/gray & Rhizoid & Rhizoid & White & White & white & Pukall (2011); \\
\hline Hemolyis & + & - & + & $(+)$ & $(+)$ & + & + & + & Jimenez et al. \\
\hline Motility & \pm & - & \pm & - & - & + & + & + & (2013); \\
\hline $\begin{array}{l}\text { Susceptibility to } \\
\text { penicillin }\end{array}$ & - & + & - & - & - & - & - & - & $\begin{array}{l}\text { Eglezos and } \\
\text { Dykes (2014); }\end{array}$ \\
\hline Parasporal crystal & - & - & + & - & - & - & - & - & Pontieri \\
\hline $\begin{array}{l}\text { Growth temperature } \\
\text { range }\left({ }^{\circ} \mathrm{C}\right)\end{array}$ & $10-45$ & $>10-<50$ & $10-45$ & $15-40$ & $10-40$ & $5-37$ & $20-50$ & $10-45$ & $\begin{array}{l}\text { (2016); } \\
\text { Lindbäck and }\end{array}$ \\
\hline $\begin{array}{l}\text { Lysis by gamma } \\
\text { phage }\end{array}$ & - & + & - & - & - & - & - & - & $\begin{array}{l}\text { granum } \\
\text { (2019); }\end{array}$ \\
\hline Catalase & + & + & + & + & + & + & + & + & Ramarao et \\
\hline Citrate utilization & + & - & + & - & - & - & - & + & al. (2020); \\
\hline $\begin{array}{l}\text { Lecithinase activity } \\
\text { (Egg yolk reaction) }\end{array}$ & \pm & $(+)$ & \pm & \pm & $(+)$ & + & $(+)$ & + & $\begin{array}{l}\text { Haque et al. } \\
(2021)\end{array}$ \\
\hline Acid from mannitol & - & - & - & - & - & - & - & - & \\
\hline $\begin{array}{l}\text { Glucose anaerobic } \\
\text { utilization }\end{array}$ & + & + & + & + & + & + & + & + & \\
\hline Reduction of nitrate & \pm & + & + & + & + & + & + & + & \\
\hline VP reaction & + & + & + & + & + & + & $(+)$ & + & \\
\hline $\begin{array}{l}\text { Tyrosine } \\
\text { decomposition }\end{array}$ & + & $(+)$ & + & $(+)$ & + & + & + & + & \\
\hline $\begin{array}{l}\text { Resistance to } \\
\text { lysozyme }\end{array}$ & + & + & + & + & + & + & + & + & \\
\hline Anaerobic growth & + & + & + & + & $(+)$ & - & $(+)$ & + & \\
\hline Starch & + & + & + & + & + & + & - & + & \\
\hline Indole & - & - & - & - & - & - & - & - & \\
\hline
\end{tabular}

a Differentiated from B. mycoides based on fatty acid composition and $16 \mathrm{~S}$ RNA sequence; bifferentiated from $B$. cereus based on growth at $<7^{\circ} \mathrm{C}$ and not at $43^{\circ} \mathrm{C}$; it can be identified rapidly using rRNA gene- or cspA (cold shock protein A gene)-targeted PCR; 'Differentiated from $B$. cereus by maximum growth at $50^{\circ} \mathrm{C}$ and minimum growth at $20^{\circ} \mathrm{C}$, by the absence of starch hydrolysis, and by the absence of growth on synthetic media without tryptophan; distinguished from other $B$. cereus group members by pairwise calculation of the average nucleotide identity; +, Positive; -, negative; (+), weakly positive; \pm , usually positive but occasionally may be negative; VP, Voges-Proskaurer

involves injecting $0.1 \mathrm{ml}$ of cell-free culture supernatant intra-dermally into $2.5-3.0 \mathrm{~kg}$ rabbits. After 3 hours, a $4 \mathrm{ml}$ intravenous injection of $2 \%$ Evans blue dye solution is given. After 1 hour the perpendicular diameters of the light and dark blue areas, as well as any necrosis, are measured. The ligated rabbit ileal loop assay involves injecting bacterial culture supernatant into a $5 \mathrm{~cm}$ ileal loop of female New Zealand White rabbits. If the amount of fluid retention to loop tube diameter is $>0.5$, the test is positive. In cytotoxicity assays, filtered supernatant is added to a cell line, and the treatment effects on the cells are assessed. The diarrheal toxins can affect a variety of cell lines, such as Vero (monkey kidney), Chinese hamster ovary (CHO), HeLa S3, Human Embryonic Lung (HEL) and McCoy cell lines (Raddadi et al. 2010).

\section{Commercial kits/immunoassays}

Enterotoxins can be detected by using different commercial immunological assays. The presence of the L2 portion of HBL and NheA is measured by the BCET-RPLA Toxin Detection kit (Oxoid, UK) and Tecra BDE-VIA kit (Tecra Diagnostics, Australia), respectively. The Duopath Cereus Enterotoxins (Merck KGaA Chemicals, Germany) test assay simultaneously detects both HBL and Nhe (Raddadi et al 2010; Lindbäck and Granum 2015).

\section{Control and prevention}

$B$. cereus and its latent spores are ubiquitously present in nature, so they can easily contaminate various types of food and degrade the organoleptic properties of food (especially eggs, meat and milk based products), affecting their market quality. This is a serious public health issue, as well as a significant economic risk for the food industry. However, due to the absence of any legislation for the systematic screening of food items for pathogen contamination, limits on the quantity of $B$. cereus cells in foodstuffs have been set in various nations and regions, based on standard recommendations (Table 9). The majority of $B$. cereus of food-borne outbreaks have been linked to bacterial concentrations $>10^{5} \mathrm{CFU} / \mathrm{g}$ of food material, while some instances are linked to number as low as $10^{3} \mathrm{CFU} / \mathrm{g}$. Furthermore, determination of a safe limit is difficult, as the pathogenicity is not only assessed by the quantity of bacterial cells. Regulation will focus on $B$. cereus group food safety, with a maximum tolerable limit (MTL) of $10^{3} \mathrm{cfu} / \mathrm{g}$ in dairy products for the general population, $10^{2} \mathrm{cfu} / \mathrm{g}$ in infant formula, $10^{3} \mathrm{cfu} / \mathrm{g}$ in RTE meat and $10^{5} \mathrm{cfu} / \mathrm{g}$ in egg products. Food processors should guarantee that $B$. cereus counts of $10^{3}-10^{5} / g$ are not reached (or surpassed) at the point of consumption under normal storage and handling settings, which must also be 
Table 8: Diagnostic marker genes for Bacillus spp.

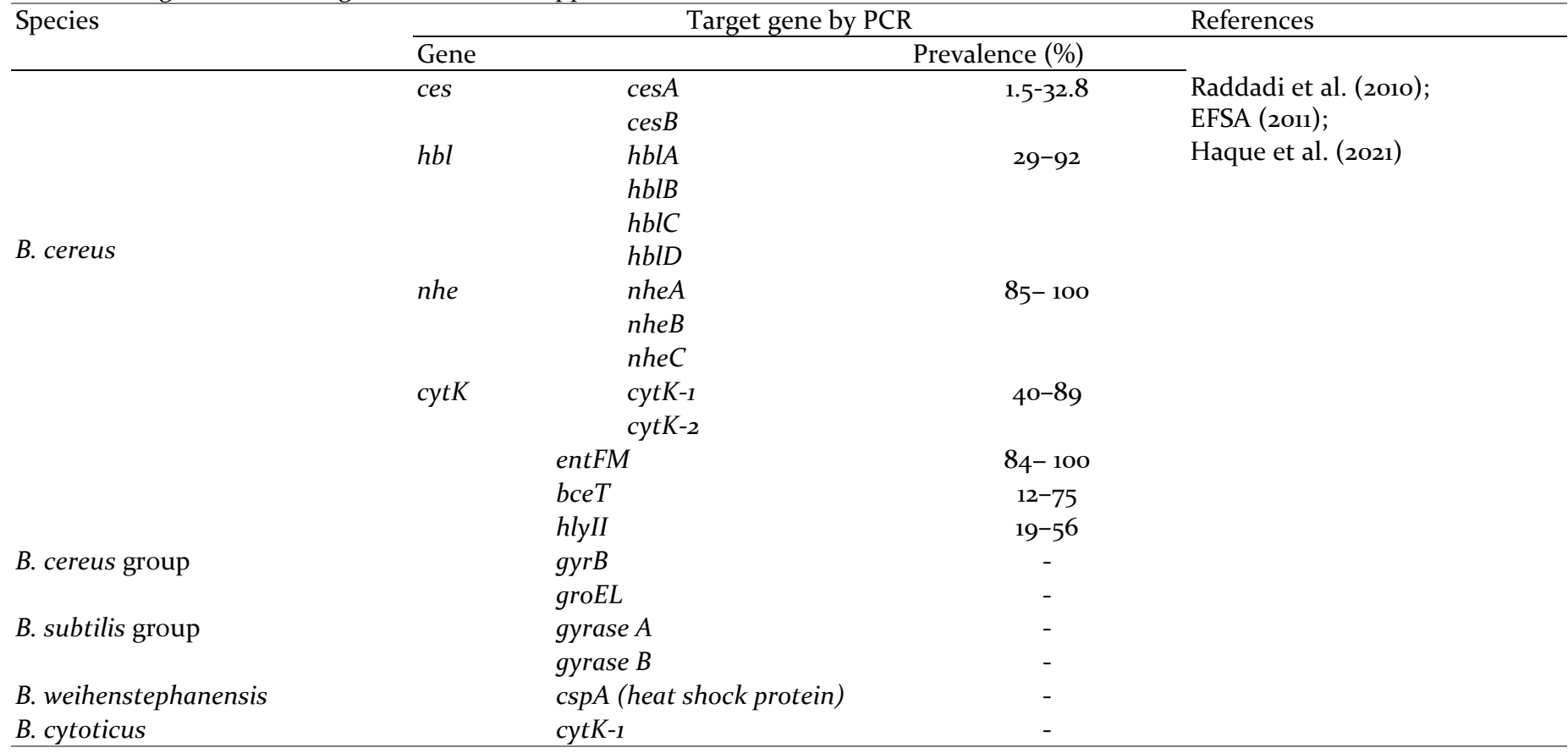

Table 9: Maximum tolerable limit (MTL) of B. cereus contamination in different foodstuffs

\begin{tabular}{lll}
\hline \multicolumn{2}{l}{ Country/authority Food items } & $\begin{array}{l}\text { MTL } \\
\text { (cfu/g) }\end{array}$ \\
\hline EU & DIF & 50 \\
CAC, FAO, WHO & IF & $10^{2}$ \\
FSANZ, Korea & RTE food & $10^{2}-<10^{3}$ \\
Ireland & RTE food & $10^{3}-<10^{4}$ \\
UK & RTE food, Dried herbs and spices & $10^{3}-<10^{4}$ \\
HPAUK, CFSHK & RTE food & $10^{3}-<10^{5}$ \\
FDA & Dairy products, cheese and cheese products & $<10^{4}$ \\
& DIF and DDF intended for infants $<6$ months of age & $10^{2}$ \\
France & Cooked ham and salami, CFP, cooked meat-based products, RTE meals, sauces, cold \\
& starters, salads containing raw vegetables and cheese, fish- or meat-based starters, $<10^{2}$ \\
Philippine & cooked starters, cured meats served hot or cold, RTE cooked pastries & $10^{5}$ \\
& Starch-rich food & $10^{2}$ \\
& Frozen entrees containing rice or corn flour as main ingredient, Tofu, CBF for infants & $10^{2}$ \\
Italy & Pasta or rice salads, cheese meals, pizza, bread, cooked products and cold served \\
& foods, pastries and biscuits, fish-based products, honey, cereals, RTE vegetables, $<10^{2}$ \\
Spain & cooked ham and salami, cheese made from pasteurized milk, gastronomic products, \\
Germany & fresh pastry, egg-based pasta, RTE dishes & $<10^{3}$ \\
Portugal & Raw vegetables, spices, herbs, sandwiches, salads containing uncooked ingredients & $<10^{3}$ \\
Croatia & Teas and derivates, herbs and spices & $<10^{3}$ \\
& Herbs and spices, tofu & $<10^{2}$ \\
& CBP, sandwiches, sprouts, RTE hot products & $<10^{2}$ \\
& Sashimi & $<5 \times 10^{2}$ \\
& Puddings, heat-treated dairy desserts and related products & $<10$
\end{tabular}

EU=European Union, $\mathrm{CAC}=$ Codex Alimentarius Commission, $\mathrm{FAO}=$ Food and Agriculture Organization of the United Nations, WHO= World Health Organization, FSANZ= Food Standards Australia New Zealand, UK=United Kingdom, HPAUK=Health Protection Agency United Kingdom, CFSHK=Centre for Food Safety, Hong Kong, FDA=Food and Drug Administration, RTE=Ready to eat, DIF=Dried infant formulae, $\mathrm{IF}=$ Infant formulae, $\mathrm{DDF}=$ Dried dietary foods, $\mathrm{CPF}=$ Cooked food products, $\mathrm{CBF}=$ Cereal base foods, $\mathrm{CBP}=\mathrm{Cereal}$ based products.

applied to rehydrated foods reconstituted with hot water before intake (Blackburn and McClure, 2009; Zhang et al. 2020; Ramarao et al. 2020; Yu et al. 2020; Haque et al. 2021). While $B$. cereus is present in many foods, its vegetative form is inhibited by most cooking methods, it still challenges with spores survival and later outgrowth remains in damp protein-based foods and rice.
Cooked foods should either be kept at a temperature above $60^{\circ} \mathrm{C}$ or quickly cooled and refrigerated below $4^{\circ} \mathrm{C}$ to prevent the growth of $B$. cereus spores (Eglezos and Dykes 2014). Bacillus strains also have the potential as promising probiotics to enhance human and animal health by consuming large amounts of live cells directly. Probiotic Bacillus spp. may possess toxicity and transmit 
ARGs between probiotics and opportunistic or pathogenic bacteria in GITs. Toxicity testing is a primary safety concern for probiotics candidates that are to be consumed by humans and livestock, thus the absence of $B$. cereus toxin and susceptibility to antibiotics in Bacillus spp. intended for use as feed additives must be thoroughly investigated. To reach a consensus on the phenotypic and genotypic characteristics of targeted Bacillus spp. and their correlation with those having generally recognized as safe (GRAS) status, the entire genome should be sequenced and analyzed to look for genes that are responsible for the production of enterotoxins and the emetic toxin.

The necessity of strain-level identification, on the other hand, is essential for detecting and removing any causative relationship between probiotics and strains obtained from immune-compromised hosts. As a result, it is critical to remember that clinical studies of these regimens should include a large proportion of the target population, including persons with poor immunity. Therefore, more work is needed to be done in terms of monitoring virulence factors, toxins and antibiotic resistance determinants in probiotic Bacillus spp. (Elshaghabee et al., 2017; Mingmongkolchai and Panbangred 2018; Cui et al. 2019; Deng et al. 2021). In addition, widespread antibiotic use can result in the development of antibiotic-resistant bacterial strains, with the potential for resistance genes to be passed on to other pathogenic and nonpathogenic bacteria, as well as the human food chain. So, it is critical to use legal antimicrobials in food-produing animals by registered health experts, maintaining withdrawal periods, limiting antimicrobials products as feed additives, to ensure proper sewage treatment of human and veterinary hospital effluents, and prohibiting the use of poultry offal, litters and livestock waste in aquaculture (Hassan et al. 2021). Antimicrobial resistance profiles and other virulence factors of Bacillus spp. have recently been evaluated, using next generation sequencing. This method could change probiotic exploration, because it can detect other probiotic characteristics, such as bacteriocin production, adhesion-ability, and signaling pathways at the genome level, in addition to safety hazards (Ramlucken et al. 2020). Organic acids (acetic, butyric, citric, formic, lactic, propionic, malic, and sorbic acids) and their salts (sodium acetate, sodium butyrate, sodium citrate, sodium formate, sodium lactate, and sodium propionate) have also been used as acidifiers in animal feeds to improve gut health and performance, as well as weight gain, survival, and FCR. Acidifiers have a similar effect to antibiotics in that they significantly regulate gut bacterial populations and boost immune response. Acidifiers coated salts are now commercially available for usage in food animals, particularly pigs and poultry. Combining organic acids with other antimicrobial substances, such as phytochemicals or permeabilizers, in an effort to use possible synergy to more efficiently combat pathogenic bacteria, fungi or mold in feed prophylactic measure, is a new emerging strategy to modulate gut microflora and reduce pathogens in the gut (Pearlin et al. 2020).
Fermented feed ingredients (soybean and corn) in herd and poultry diets, as well as soybean food for human consumption, may contain $B$. cereus vehicles that can be regulated using uniform fermentation principles, such as the structure and composition of the testing products, the basic culture technique, fermentation criteria, postfermentation methods and the utilization of bacterial peptides, bacteriocins and other antimicrobials (Haque et al. 2021). Since the emergence of antibiotic-resistant bacteria, phage endolysins, especially LysB4EAD-LysSAn, hybrid endolysin have piqued interest as a promising alternative to antibacterial agents for the simultaneous control of multiple bacteria, including $B$. cereus. Furthermore, this strategy would allow for the development of multifunctional and highly specific antimicrobials, thereby reducing the prevalence of multidrug-resistant bacteria (Son et al. 2020). Besides this, natural antibacterial agents, such as Makino, Asteraceae, Roselle, Rosemary, clove, thyme and others, may be possible candidates for the production of new strategies to combat the spread of $B$. cereus in the food and feed industry (Haque et al. 2021).

\section{REFERENCES}

Abbasian $F$ et al., 2018. Microbiological sensing technologies: A review. Bioengineering 5: 1-33.

Abdeen EES et al., 2020. Prevalence of virulence determinants among Bacillus cereus from milk products with potential public health concern. Pakistan Journal of Biological Sciences 23: 206-212.

Abou Zeid MAM and Yassin SA, 2017. Detection of some virulence factors of Bacillus cereus in heat-treated milk. Alexandria Journal of Veterinary Sciences 53: 7278.

Abouelhag HA et al., 2021. Prevalence, antibiogram pattern and virulence genes profile of Bacillus cereus isolated from buffalo milk. International Journal of Veterinary Science. 10: 234-239.

Adame-Gomez R et al., 2020. Prevalence of the strains of Bacillus cereus group in artisanal Mexican cheese. Foodborne Pathogens and Disease 17: 8-14.

Adesetan TO et al., 2019. Biochemical characterization and antimicrobial susceptibility of Bacillus cereus isolates from some retailed foods in Ogun state, Nigeria. Journal of Microbiology, Biotechnology and Food Science 9: 616-621.

Al-Abri SS et al., 2011. A hospital acquired outbreak of Bacillus cereus gastroenteritis, Oman. Journal of Infection and Public Health 4: 180-186.

Al-Jobory LSA and Abdulaal NI, 2020. Checkerboard pattern of green tea and rosemary extracts on multi drugs resistant Bacillus cereus recovered from soft cheese in Kirkuk, Iraq. Plant Archives 20: 6799-6805.

Ankolekar C et al., 2009. Detection of toxigenic Bacillus cereus and Bacillus thuringiensis spores in U.S. rice. International Journal of Food Microbiology 28: 46o466.

Arsene MMJ et al., 2021. The use of probiotics in animal feeding for safe production and as potential 
alternatives to antibiotics. Veterinary World 14: 319328.

Banerjee $\mathrm{M}$ et al., 2011. Phenotypic and genetic characterization of Bacillus cereus isolated from the acute diarrheal patients. Indian Journal of Medical Research 133: 88-95.

Bao $\mathrm{H}$ et al., 2020. Rapid and simple detection of Bacillus cereus in milk by real-time competitive annealing mediated isothermal amplification. The Analyst 145(20): doi: 10.1039/DoANoo965B.

Batchoun $\mathrm{R}$ et al., 2011. Molecular characterization of Bacillus cereus toxigenic strains isolated from different food matrices in Jordan. Foodborne Pathogens and Disease 8: 1153-1158.

Berthold-Pluta A et al., 2019. Prevalence and toxicity characterization of Bacillus cereus in food products from Poland. Foods 8: 1-12.

Bilal $\mathrm{M}$ et al., 2020. Effects of novel probiotic strains of Bacillus pumilus and Bacillus subtilis on production, gut health and immunity of broiler chickens raised under suboptimal conditions. Poultry Science 100: 1-11.

Blackburn CDW and PJ McClure, 2009. Pathogenic Bacillus species: Foodborne Pathogens, 2nd Ed., Woodhead Publishing Series in Food Science, Technology and Nutrition, pp: 844-888.

Carlin F and Nguyen-The C, 2013. Pathogen update: Bacillus species: Advances in Microbial Food Safety, Woodhead Publishing Limited; pp: 70-96.

Carroll LM et al., 2019. Characterization of emetic and diarrheal Bacillus cereus strains from a 2016 foodborne outbreak using whole-genome sequencing: Addressing the microbiological, epidemiological and bioinformatic challenges. Frontiers in Microbiology 10: 1-20.

Carroll LM et al., 2020. Proposal of a taxonomic nomenclature for the Bacillus cereus group which reconciles genomic definitions of bacterial species with clinical and industrial phenotypes. mBio 11: 1-20.

Chang HJ et al., 2011. Prevalence of the levels of Bacillus cereus in fried rice dishes and its exposure assessment from Chinese-style restaurants. Food Science and Biotechnology 20: 1351-1359.

Chaves JQ et al., 2017. Molecular characterization and risk assessment of Bacillus cereus sensu lato isolated from ultrahigh-temperature and pasteurized milk marketed in Rio de Janeiro, Brazil. Journal of Food Protection 8o: 1060-1065.

Chen D et al., 2019. A foodborne outbreak of gastroenteritis caused by Norovirus and Bacillus cereus at a university in the Shunyi district of Beijing, China 2018: A retrospective cohort study. BMC Infectious Diseases 19: 1-6.

Choi KB et al., 2011. Epidemiological investigation for outbreak of food poisoning caused by Bacillus cereus among the workers at a local company in 2010. Journal of Preventive Medicine and Public Health 44: 65-73.

Chon JW et al., 2012. Prevalence, phenotypic traits and molecular characterization of emetic toxin-producing Bacillus cereus strains isolated from human stools in Korea. Journal of Applied Microbiology 112: 1042-1049.
Chon JW et al., 2015. Quantitative prevalence and toxin gene profile of Bacillus cereus from ready-to-eat vegetables in South Korea. Foodborne Pathogens and Disease 12: 795-799.

Chrun et al., 2017. Microbiological hazard contamination in fermented vegetables sold in local markets in Cambodia. Biocontrol Science 22: 181-185.

Cui Y et al., 2016. Characterization of Bacillus cereus isolates from local dairy farms in China. FEMS Microbiology Letters 363: 1-6.

Cui Y et al., 2019. Multifaceted toxin profile, an approach toward a better understanding of probiotic Bacillus cereus. Critical Reviews in Toxicology 49: 342-356.

Dallal SMM et al., 2017. To determine the frequency of Bacillus cereus in powdered milk infant formula consuming in neonatal intensive care unit (nicu) in Tehran hospitals in 2013-14. Iranian South Medical Journal 19: 982-988.

Delbrassinne L and Mahillon J, 2016. Bacillus: Occurrence: Encyclopedia of Food and Health, Elsevier Ltd. pp: 307-311.

Delbrassinne L et al., 2012. Prevalence and levels of Bacillus cereus emetic toxin in rice dishes randomly collected from restaurants and comparison with the levels measured in a recent foodborne outbreak. Foodborne Pathogens and Disease 9: 809-814.

Deng $F$ et al., 2021. Antimicrobial resistance, virulence characteristics and genotypes of Bacillus spp. from probiotic products of diverse origins. Food Research International 139: 1-9.

Depo $\mathrm{M}$ et al., 2018. Bacillus cereus contamination of donated food for an orphanage in Gunung Kidul district, Indonesia, 2017. Proceedings of "9th TEPHINET Bi-regional Conference” Lao PDR, 2018.

Dichtl K et al., 2019. Food poisoning: An underestimated cause of Boerhaave syndrome. Infection 48: 125-128.

Dierick K et al., 2005. Fatal family outbreak of Bacillus cereus-associated food poisoning. Journal of Clinical Microbiology 43: 4277-4279.

Ehling-Schulz M et al., 2019. The Bacillus cereus group: Bacillus species with pathogenic potential. Microbiology Spectrum 7: 1-35.

Ehling-Schulz $M$ and Messelhäusser U, 2012. One pathogen but two different types of foodborne outbreak: Bacillus cereus in catering facilities in Germany: Case Studies in Food Safety and Authenticity. Woodhead Publishing series in Food Science, Technology and Nutrition 63-70.

Ehling-Schulz M et al., 2011. Bacillus cereus in milk and dairy production. In: Hoorfar J (editor). Rapid Detection, Identification, and Quantification of Foodborne Pathogens. ASM Press, Washington, DC; USA, pp: 275-289.

EFSA, 2011. Panel on additives and products or substances used in animal feed (FEEDAP): Technical guidance on the assessment of the toxigenic potential of Bacillus species used in animal nutrition. EFSA Journal 9: 2445 .

EFSA (European Food Safety Authority) and ECDC (European Centre for Disease Prevention and 
Control), 2016. The European Union summary report on trends and sources of zoonoses, zoonotic agents and food-borne outbreaks in 2015. EFSA Journal 14: 4634 .

Eglezos S and Dykes GA, 2014. Microbiological safety of meat, Bacillus cereus: Encyclopedia of Meat Sciences, and Ed., Elsevier Ltd. pp: 324-329.

Elias SDO et al., 2018. Foodborne outbreaks in Brazil associated with fruits and vegetables: 2008 through 2014. Food Quality and Safety 2: 173-181.

Elshaghabee FMF et al., 2017. Bacillus as potential probiotics: Status, concerns, and future perspectives. Frontiers in Microbiology 8: 1-15.

Enan G et al., 2020. Incidence of Bacillus cereus in Egyptian foods and its control by probiotics. Bioscience Research 17: 550-559.

Flores-Urban KA et al., 2014. Detection of toxigenic Bacillus cereus strains isolated from vegetables in Mexico City. Journal of Food Protection 77: 2144-2147.

Food safety authority of Ireland, 2016. https://www.scribd.com/document/3906ooo11/ Bacillus-Cereus-Factsheet-2016-FINAL-ACCESSIBLE

Fritze D and Pukall R, 2012. Culture media for Bacillus spp. and related genera relevant to foods. In: Corry JEL, Curtis GDW, Baird RM (editors). Handbook of Culture Media for Food and Water Microbiology. 3rd Ed., Royal Society of Chemistry, pp: 90-114.

Gharib AA et al., 2020. Multiplex polymerase chain reaction for detection of toxin genes of Bacillus cereus group isolated from meat and chicken products. Zagazig Veterinary Journal 48: 457-470.

Griffiths MW, 2010. Bacillus cereus and other Bacillus spp. In: Juneja VK, Sofos JN (editors). Pathogens and Toxins in Foods: Challenges and Interventions; ASM Press, Washington, DC, USA; pp: 1-19.

Griffiths MW and Schraft H, 2017. Bacillus cereus Food Poisoning: Foodborne Diseases, 3rd Ed., Academic Press, Elsevier Inc. pp: 395-405.

Grutsch AA et al., 2018. Bacillus spp. as pathogens in the dairy industry: Foodborne Diseases, Academic Press, Elsevier Inc. pp: 193-211.

Güven K and Mutlu MB, 2009. Properties of Bacillus cereus collected from different food sources. Turkish Journal of Biology 33: 101-108.

Gwack J et al., 2010. Trends in water and foodborne disease outbreaks in Korea, 2007-2009. Osong Public Health and Research Perspectives 1: 50-54.

Haque MA et al., 2021. Pathogenicity of feed-borne Bacillus cereus and its implication on food safety. Agrobiological Records 3: 1-16.

Hassan MM et al., 2021. Residual antimicrobial agents in food originating from animals. Trends in Food Science and Technology 111: 141-150.

Heini $\mathrm{N}$ et al., 2018. Characterization of Bacillus cereus group isolates from powdered food products. International Journal of Food Microbiology 283: 5964.

Hernandoa V et al., 2007. Investigation of a foodborne intoxication in a high-density penitentiary center. Gaceta Sanitaria 21: 452-457.
Heydarzadeh $\mathrm{M}$ et al., 2020. Detection of emetic toxin (ces) gene and antimicrobial susceptibility of Bacillus cereus isolates from Iranian traditional dairy products. Research Square. 2020: 1-13.

Ichikawa K et al., 2010. Acute encephalopathy of Bacillus cereus mimicking Reye syndrome. Brain and Development 32: 688-690.

Jimenez G et al., 2013. Description of Bacillus toyonensis sp. nov., a novel species of the Bacillus cereus group, and pairwise genome comparisons of the species of the group by means of ANI calculations. Systematic and Applied Microbiology 36: 383-391.

Kalbhenn EM et al., 2021. Detection and isolation of emetic Bacillus cereus toxin cereulide by reversed phase chromatography. Toxins 13: 1-14.

Kim CW et al., 2015. Prevalence, genetic diversity and antibiotic resistance of Bacillus cereus isolated from Korean fermented soybean products. Journal of Food Science 80: 123-128.

Kim JB et al., 2010. Food poisoning associated with emetic-type of Bacillus cereus in Korea. Foodborne Pathogens and Disease 7: 555-563.

Kim JH et al., 2009. A case of emetic toxin producing Bacillus cereus strains isolated from outbreak. Korean Journal of Clinical Microbiology 12: 48-52.

Kim SO and Kim SS, 2020. Bacterial pathogen detection by conventional culture-based and recent alternative (polymerase chain reaction, isothermal amplification, enzyme linked immunosorbent assay, bacteriophage amplification and gold nanoparticle aggregation) methods in food samples: A review. Journal of Food Safety 2020: 1-12.

Kim SO and Kim SS, 2021. Recent (2011-2017) foodborne outbreak cases in the Republic of Korea compared to the United States: A review. Food Science and Biotechnology 30: 185-194.

Kong L et al., 2021. An investigation on the occurrence and molecular characterization of Bacillus cereus in meat and meat products in China. Foodborne Pathogens and Disease 2021: 1-9.

Kumari S and Sarkar PK, 2016. Bacillus cereus hazard and control in industrial dairy processing environment. Food Control 69: 20-29.

Latsios G et al., 2003. Liver abscess due to Bacillus cereus: A case report. Clinical Microbiology and Infection 9: 1234-1237.

Lentz SAM et al., 2018. Bacillus cereus as the main causal agent of foodborne outbreaks in Southern Brazil: Data from 11 years. Cadernos de Saúde Pública 34: 1-9.

Lesley MB et al., 2017. Detection of Bacillus cereus in formula milk and ultra-high temperature (UHT) treated milk products. International Food Research Journal 24: 985-989.

Li X, 2020. Gastric ulceration and immune suppression in weaned piglets associated with feed-borne Bacillus cereus and Aspergillus fumigatus. Toxins 12: 1-13.

Liao SL and Tsai MH, 2020. Bacillus cereus bacteremia in a preterm infant caused by consumption of contaminated breast milk. Pediatrics and Neonatology 62: 337-338. 
Lin $\mathrm{KH}$ and $\mathrm{Yu} \mathrm{YH}$, 2020. Evaluation of Bacillus licheniformis-fermented feed additive as an antibiotic substitute: Effect on the growth performance, diarrhea incidence, and cecal microbiota in weaning piglets. Animals 10: 1-16.

Lindbäck T and Granum PE, 2015. Bacillus cereus phospholipases, enterotoxins, and other hemolysins: The Comprehensive Sourcebook of Bacterial Protein Toxins, 4th Ed., Academic press, Elsevier Ltd. pp: 839857.

Lindbäck T and Granum PE, 2019. Bacillus cereus. In: Doyle MP, Diez-Gonzalez F and Hill C (editors). Food Microbiology: Fundamentals and Frontiers, $5^{\text {th }}$ Ed., ASM Press, Washington, DC, USA, pp: 541-554.

Liu Y et al., 2018. Detection of Bacillus cereus sensu lato from environments associated with goat milk powdered infant formula production facilities. International Dairy Journal.83: 10-16

Liu XY et al., 2020. Characterization of Bacillus cereus in dairy products in China. Toxins 12: 1-18.

Lopez AC et al., 2015. A case of intoxication due to a highly cytotoxic Bacillus cereus strain isolated from cooked chicken. Food Microbiology 46: 195-199.

Lutpiatina L, 2020. Pathogens transmitted through contaminated rice, In: Recent Advances in Rice Research. IntechOpen. doi:10.5772/intechopen.93757

May FJ et al., 2016. Epidemiology of bacterial toxinmediated foodborne gastroenteritis outbreaks in Australia, 2001 to 2013 Communicable Diseases Intelligence 40: 460-469.

McIntyre L et al., 20o8. Identification of Bacillus cereus group species associated with food poisoning outbreaks in British Columbia, Canada. Applied and Environmental Microbiology 74: 7451-7453.

McLauchlin J et al., 2016. Assessment of the microbiological quality of meat pies from retail sale in England 2013. Journal of Food Protection 79: 781-788.

Messelhausser U et al., 2014. Emetic Bacillus cereus are more volatile than thought: Recent foodborne outbreaks and prevalence studies in Bavaria (20072013). BioMed Research International 2014: 1-9.

Mingmongkolchai S and Panbangred W, 2018. Bacillus probiotics: An alternative to antibiotics for livestock production. Journal of Applied Microbiology 124: 13341346.

Mishra SS et al., 2020. Biotechnological tools in diagnosis and control of emerging fish and shellfish diseases. In: Genomics and Biotechnological Advances in Veterinary, Poultry and Fisheries, Academic Press pp: 311-36o.

Mohamed WS and Ghanyem HR, 2015. Effect of some preservatives on Bacillus cereus isolated from some meat products. Assiut Veterinary Medical Journal 61: $1-7$.

Naranjo M et al., 2011. Sudden death of a young adult associated with Bacillus cereus food poisoning. Journal of Clinical Microbiology 49: 4379-4381.

Navaneethan Y and Esah EM, 2020. Prevalence, toxigenic profiles, multidrug resistance, and biofilm formation of Bacillus cereus isolated from ready-to eat cooked rice in Penang, Malaysia. Food Control 121: 1-10.

Osimani A et al., 2018. Bacillus cereus foodborne outbreaks in mass catering. International Journal of Hospitality Management 72: 145-153.

Pearlin BV et al., 2020. Role of acidifiers in livestock nutrition and health: A review. Journal of Animal Physiology and Animal Nutrition 104: 558-569.

Pirhonen TI et al., 2005. Biochemical and toxic diversity of Bacillus cereus in a pasta and meat dish associated with a food-poisoning case. Food Microbiology 22: 8791.

Pontieri E, 2016. Bacillus cereus group diagnostics. In: Savini V (editor), The Diverse Faces of Bacillus cereus. Academic Press, Elsevier Inc. pp: 15-33.

Posfay-Barbe KM et al., 20o8. Food poisoning as a cause of acute liver failure. The Pediatric Infectious Disease Journal 27: 846-847.

Quinn et al., 2016. Concise Review of Veterinary Microbiology. 2nd Ed., Wiley Blackwell, West Sussex, UK.

Raddadi $\mathrm{N}$ et al., 2010. Bacillus. In: Liu D (editor), Molecular Detection of Foodborne Pathogens, CRC Press Taylor \& Francis Group, Boca Raton, London, New York; pp: 129-144.

Rafique A et al., 2020. Multiplex PCR based detection of toxin producing Bacillus cereus from different milk samples retailed in Pakistan. Pakistan Journal of Agricultural Sciences 57: 887-891.

Ramarao $\mathrm{N}$ et al., 2020. Advanced methods for detection of Bacillus cereus and its pathogenic factors. Sensors 20: 1-23.

Ranjbar R and Shahreza MHS, 2017. Prevalence, antibiotic-resistance properties and enterotoxin gene profile of Bacillus cereus strains isolated from milkbased baby foods. Tropical Journal of Pharmaceutical Research 16: 1931-1937.

Rigourd V et al., 2018. Recent actuality about Bacillus cereus and human milk bank: A new sensitive method for microbiological analysis of pasteurized milk. European Journal of Clinical Microbiology and Infectious Diseases 37: 1297-1303.

Rodrigo D et al., 2021. Risk of Bacillus cereus in relation to rice and derivatives. Foods 10: 1-11.

Ramlucken U et al., 2020. Advantages of Bacillus based probiotics in poultry production. Livestock Science 241: 104215; doi:10.1016/j.livsci.2020.104215.

Sahu R et al., 2021. Acute gastroenteritis outbreak in a school associated with religious ceremony in Mirzapur district, Uttar Pradesh, India. Indian Journal of Public Health 65: 18-22.

Saleh M et al., 2012. Bacillus cereus, an unusual cause of fulminant liver failure: Diagnosis may prevent liver transplantation. Journal of Medical Microbiology 61: 743-745.

Saleh-Lakha $\mathrm{S}$ et al., 2017. A study to assess the numbers and prevalence of Bacillus cereus and its toxins in pasteurized fluid milk. Journal of Food Protection 8o: 1085-1089.

Samapundo $\mathrm{S}$ et al., 2011. Incidence, diversity and toxin gene characteristics of Bacillus cereus group strains 
isolated from food products marketed in Belgium. International Journal of Food Microbiology 150: 34-41.

Sanchez-Chica J et al., 2020. Genetic and toxigenic diversity of Bacillus cereus group isolated from powdered foods. Journal of Food Science and Technology. 58: 1892-1899.

Scatassa ML et al., 2018. Retrospective study on the hygienic quality of fresh ricotta cheeses produced in Sicily, Italy. Italian Journal of Food Safety 7: 68-71.

Schlegelova J et al., 2003. The prevalence of and resistance to antimicrobial agents of Bacillus cereus isolates from foodstuffs. Veterinary Medicine-Czech 48: 331-338.

Shawish R and Tarabees R, 2017. Prevalence and antimicrobial resistance of Bacillus cereus isolated from beef products in Egypt. Open Veterinary Journal 7:337-341.

Shiota M et al., 2010. Rapid detoxification of cereulide in Bacillus cereus food poisoning. Pediatrics 125: 951-955.

Sloan-Gardner TS et al., 2014. An outbreak of gastroenteritis linked to a buffet lunch served at a Canberra restaurant. Communicable Diseases Intelligence 38: 273-278.

Smith DP et al., 2004. Detection of Bacillus cereus on selected retail chicken products. Journal of Food Protection 67: 1770-1773.

Soleimani $\mathrm{M}$ et al., 2017. Occurrence of Bacillus cereus in beef burger marketed in Tehran, capital of Iran. Journal of Food Quality and Hazards Control 4: 70-73.

Son B et al., 2020. Simultaneous control of Staphylococcus aureus and Bacillus cereus using a hybrid endolysin LysB4EAD-LysSA11. Antibiotics 9: 1-11.

Sornchuer P and Tiengtip R, 2021. Prevalence, virulence genes, and antimicrobial resistance of Bacillus cereus isolated from foodstuffs in Pathum Thani Province, Thailand. Pharmaceutical Sciences Asia 48: 194-203.

Tewari A and Abdullah S, 2015. Bacillus cereus food poisoning: International and Indian perspective. Journal of Food Science and Technology 52: 2500-2511.

Tewari A et al., 2012. Prevalence of multidrug resistant Bacillus cereus in foods and human stool samples in and around Pantnagar, Uttrakhand. Journal of Advanced Veterinary Research 2: 252-255.

Thirkell CE et al., 2019. An outbreak of Bacillus cereus toxin-mediated emetic and diarrheal syndromes at a restaurant in Canberra, Australia 2018. Communicable Diseases Intelligence 43: 1-9.

Tirlonia E et al., 2019. Bacillus cereus in fried rice meals: Natural occurrence, strain dependent growth and haemolysin (HBL) production. LWT - Food Science and Technology 114: 1-7

Tschiedel E et al., 2015. Lifesaving liver transplantation for multi-organ failure caused by Bacillus cereus food poisoning. Pediatric Transplantation 19: 11-14.
Ubong A et al., 2020. Prevalence of Bacillus cereus s.l. in ultra-high temperature chocolate milk from selected milk manufacturers in Malaysia. Food Research 4: 982 - 990 .

Visiello R et al., 2016. Bacillus cereus hemolysins and other virulence factors. In: The Diverse Faces of Bacillus cereus. Elsevier Inc. pp: 35-44.

Vidic J et al., 2020. Food Sensing: Detection of Bacillus cereus spores in dairy products. Biosensors 10: 1-16.

Yap $\mathrm{M}$ et al., 2019. Microbial quality and safety of sushi prepared with gloved or bare hands: Food handlers' impact on retail food hygiene and safety. Journal of Food Protection 82: 615-622.

Yibar A et al., 2017. Prevalence, enterotoxin production and antibiotic resistance of Bacillus cereus isolated from milk and cheese. Kafkas Universitesi Veteriner Fakultesi Dergisi 23: 635-642.

Yin $\mathrm{W}$ et al., 2020. Cyclic di-GMP signaling systems in the gram-positive Bacillus cereus group. In: Microbial Cyclic Di-Nucleotide Signaling, Chou et al. (editors). Springer Nature Switzerland AG, pp: 261-275.

Yu P et al., 2019. Bacillus cereus isolated from vegetables in China: Incidence, genetic diversity, virulence genes, and antimicrobial resistance. Frontiers in Microbiology 10: 1-10.

Yu S et al., 2020. A Study on prevalence and characterization of Bacillus cereus in ready-to-eat foods in China. Frontiers in Microbiology 10: 1-11.

Zeighami H et al., 2020. Frequency of hemolysin BL and non-hemolytic enterotoxin complex genes of Bacillus cereus in raw and cooked meat samples in Zanjan, Iran. Toxicology Reports 7: 89-92.

Zhang Y et al., 2017. Quantitative prevalence, phenotypic and genotypic characteristics of Bacillus cereus isolated from retail infant foods in China. Foodborne Pathogens and Disease 14: 564-572.

Zhang Q et al., 2019. Contaminated feed-borne Bacillus cereus aggravates respiratory distress post avian influenza virus $\mathrm{H}_{9} \mathrm{~N}_{2}$ infection by inducing pneumonia. Scientific Reports 9: 1-9.

Zhang Y et al., 2020. Prevalence, virulence feature, antibiotic resistance and MLST typing of Bacillus cereus isolated from retail aquatic products in China. Frontiers in Microbiology 11: 1-9.

Zhou G et al., 2014. Characterization of three Bacillus cereus strains involved in a major outbreak of food poisoning after consumption of fermented black beans (Douchi) in Yunan, China. Foodborne Pathogens and Disease 11: 769-774.

Zuo Z et al., 2020. Feed-borne Bacillus cereus exacerbates respiratory distress in birds infected with Chlamydia psittaci by inducing hemorrhagic pneumonia. Avian Pathology 49: 251-260. 